\title{
Age Constraints and Geochemistry of the Ordovician Tyrone Igneous Complex, Northern Ireland: implications for the Grampian orogeny
}

\author{
M. R. COOPER ${ }^{1}$, Q. G. CROWLEY ${ }^{2}$, S. P. HOLLIS ${ }^{3}$, S. R. NOBLE ${ }^{4}$, S. ROBERTS ${ }^{3}$, \\ D. CHEW $^{2}$, G. EARLS ${ }^{1}$, R. HERRINGTON ${ }^{5} \&$ R. J. MERRIMAN ${ }^{6}$. \\ ${ }^{1}$ Geological Survey of Northern Ireland, Colby House, Stranmillis Court, Belfast, BT9 \\ 5BF, UK (mark.cooper@detini.gov.uk) \\ ${ }^{2}$ School of Natural Sciences, Department of Geology, Trinity College, Dublin 2, \\ Ireland \\ ${ }^{3}$ School of Ocean \& Earth Science, National Oceanography Centre, University of \\ Southampton, Southampton, UK \\ ${ }^{4}$ NERC Isotope Geosciences Laboratory, British Geological Survey, Kingsley \\ Dunham Centre, Keyworth Nottingham, UK \\ ${ }^{5}$ Department of Mineralogy, Natural History Museum, London, UK \\ ${ }^{6}$ British Geological Survey, Kingsley Dunham Centre, Keyworth Nottingham, UK
}

\begin{abstract}
The Tyrone Igneous Complex is one of the largest areas of ophiolitic and arc-related rocks exposed along the northern margin of Iapetus within the British and Irish Caledonides. New U-Pb zircon data and regional geochemistry, suggest the Tyrone Plutonic Group represents the uppermost portions of a c. $480 \mathrm{Ma}$ suprasubduction zone ophiolite accreted onto an outboard segment of Laurentia prior to $470.3 \pm 1.9 \mathrm{Ma}$. The overlying Tyrone Volcanic Group formed as an island arc which collided with the Laurentian Margin during the Grampian phase of the Caledonidan orogeny. Early magmatism is characterized by transitional to calcalkaline, light rare earth element-enriched island-arc signatures, with an increasing component of continentally-derived material up sequence. Tholeiitic rhyolites with flat to U-shaped rare earth element profiles and light rare earth element-depleted basalts, located stratigraphically below a $c .473$ Ma rhyolite of the upper Tyrone Volcanic Group, suggest initiation of intra-arc rifting at c. 475 Ma. Metamorphic cooling ages from the Tyrone Central Inlier imply arc-continent collision before $468 \pm$ 1.4 Ma, with the emplacement of the Tyrone Volcanic Group onto the margin. A suite of $470.3 \pm 1.9 \mathrm{Ma}$ to $464.3 \pm 1.5 \mathrm{Ma}$ calc-alkaline intrusions are associated with the continued closure of Iapetus.
\end{abstract}

Keywords: Tyrone Igneous Complex, age constraints, geochemistry, Grampian orogenisis, Appalachian-Caledonian.

Supplementary material: geochemical data and petrography are available at www.geolsoc.org.uk/SUP00000 


\section{Introduction}

The Grampian phase of the Caledonian orogeny records collision between the passive continental margin of Laurentia and a Lower Paleozoic oceanic arc(s) during the Early to Middle Ordovician (Dewey \& Shackleton 1984). Predating final closure of the Iapetus Ocean, this was the first orogenic event to affect the southeast margin of Laurentia, broadly equivalent to the Taconic event of the Appalachians (van Staal et al. 1998). Widespread c. 490-480 Ma ophiolite obduction (Chew et al. 2010) was followed by polyphase deformation and metamorphism of thick post-Grenville, Neoproterozoic cover sequences along the Laurentian margin, such as the Dalradian Supergroup (c. 475 to $465 \mathrm{Ma}$; reviewed in Chew 2009). Orogeny was remarkably short-lived due to an associated subduction polarity reversal (Friedrich et al. 1999; Dewey 2005).

In Scotland, the colliding volcanic arc (Midland Valley terrane) is separated from the Laurentian margin by the Highland Boundary Fault (Fig. 1a), a continuation of the Baie Verte - Brompton Line of Newfoundland and the Fair Head - Clew Bay Line of Ireland (Fig. 1b). Ophiolitic rocks are preserved within this fault zone as the Highland Border ophiolite of Scotland, part of the Highland Border Complex, (Tanner 2007) and the dismembered Deer Park ophiolitic mélange of western Ireland, part of the accretionary Clew Bay Complex (Ryan et al. 1983). Remnants of the colliding $\operatorname{arc}(\mathrm{s})$ are represented within the Irish Caledonides as the Lough Nafooey, Tourmakeady and Charlestown Groups of western Ireland (e.g. Ryan et al. 1980; Clift \& Ryan 1994; Draut et al. 2004), and Tyrone Volcanic Group of Northern Ireland (Cooper et al. 2008; Draut et al. 2009). The South Mayo Trough represents the forearc to post-collisional foreland basin of the colliding Lough Nafooey arc (Dewey \& Ryan 1990).

The Dunnage Zone of central Newfoundland and Maritime Canada includes a complex association of Cambro-Ordovician arc and back-arc complexes of both intraoceanic and continental affinity which were accreted to the Laurentian margin during the Taconic event (van Staal et al. 2007) (Fig. 1b). Peri-Laurentian tracts of the Notre Dame and Dashwoods Subzones are separated from those of peri-Gondwanan affinity within the Exploits Subzone by the Red Indian Line (Williams et al. 1988). Within 
the Notre Dame Subzone, three distinct phases of the Taconic event are recognized (van Staal et al. 2007). Broad correlations have been made between the Caledonides and Newfoundland Appalachians (e.g. van Staal et al. 1998), although exact correlations between terranes often remain contentious.

The Tyrone Igneous Complex of Northern Ireland provides one of the most complete sections through an accreted arc within the Grampian belt of the Caledonides. Whole rock geochemical data published by Angus (1977) and Draut et al. (2009) detail the evolution of the complex, constrained by four U-Pb zircon dates (Hutton et al. 1985; Cooper et al. 2008; Draut et al. 2009). These data nevertheless only partially characterize the geochronology and geochemistry of the entire complex. This paper presents a total of nine new $\mathrm{U}-\mathrm{Pb}$ zircon ages, which are combined with existing $\mathrm{U}-\mathrm{Pb}$ and biostratigraphical age constraints, field relations and new regional geochemistry to shed further light on the Grampian orogenic evolution of the Caledonide - Appalachian orogen (Fig. 1c).

\section{Tyrone Igneous Complex}

The Ordovician Tyrone Igneous Complex extends over an area of about $350 \mathrm{~km}^{2}$ in the counties of Tyrone and Londonderry, Northern Ireland, and is one of the most extensive areas of ophiolitic and arc-related rocks exposed along the northern margin of Iapetus within the British and Irish Caledonides. Building on the comprehensive survey of Hartley (1933), the Tyrone Igneous Complex was divided into two distinct units: the Tyrone Plutonic Group and the Tyrone Volcanic Group (Cobbing et al. 1965; Geological Survey of Northern Ireland 1979, 1983, 1995). The complex overlies sillimanite-grade paragneisses of the Tyrone Central Inlier, which based on detrital zircon age profiling, appears to be of upper Dalradian, Laurentian affinity (Chew et al. 2008). Both the Tyrone Igneous Complex and Tyrone Central Inlier are intruded by a suite of arc-related tonalitic to granitic intrusions (Cooper \& Mitchell 2004) (Fig. 2).

\section{$\underline{\text { Tyrone Central Inlier }}$}



semipelitic paragneisses (Hartley 1933) termed the Corvanaghan Formation (GSNI

112 1995). Metamorphism is characterized by a prograde assemblage of biotite +

113 plagioclase + sillimanite + quartz \pm muscovite \pm garnet in pelitic lithologies (c. $670 \pm$ $114113{ }^{\circ} \mathrm{C}, 6.8 \pm 1.7 \mathrm{kbar}$; Chew et al. 2008), with corderite locally observed (Hartley 115 1933). Recent detrital zircon age profiling suggests an upper Dalradian, Laurentian

116 affinity for these metasediments, with Paleoproterozoic Nd model ages overlapping 117 with those from both the Argyll and Southern Highland groups (Chew et al. 2008), 118 while in situ $\mathrm{Hf}$ isotope analysis of zircon rims from c. 470Ma granitoid rocks that cut 119 the Tyrone Central Inlier paragneisses yield negative $\varepsilon_{\mathrm{Hf}} 470$ values of approximately $120-39$. This isotopic signature requires an Archaean source, suggesting rocks similar to 121 the Lewisian Complex of Scotland occur at depth beneath the Tyrone Central Inlier 122 (Flowerdew et al. 2009). The Tyrone Central Inlier is believed to represent part of an 123 outboard segment of Laurentia, most likely detached as a microcontinent prior to arc124 continent collision and reattached during the Grampian event (Chew et al. 2010).

$\underline{\text { Tyrone Plutonic Group }}$

The Tyrone Plutonic Group forms the southern, structurally lower portion of the Tyrone Igneous Complex and consists mainly of variably tectonised and metamorphosed, layered, isotropic and pegmatitic gabbros (Cobbing et al. 1965;

130 Cooper \& Mitchell 2004). Olivine gabbro at Scalp (Fig. 2) displays cumulate 131 layering, reflecting textural and compositional variations (see Cooper \& Mitchell 132 2004), with gabbro locally altered to hornblende schist (Cobbing et al. 1965). At 133 Black Rock (Fig. 2), coarse-grained hornblende gabbro is in contact with, and 134 contains xenoliths of, an early-formed suite of dolerite, itself intruded by younger 1-2 135 m wide, basalt and dolerite dykes (Cooper \& Mitchell 2004). Irregular veins of 136 pegmatitic gabbro are closely associated. In Carrickmore Quarry, parallel NE-SW trending dolerite dykes display two-sided, and more commonly one-sided, chilled margins characteristic of a sheeted dyke complex (Hutton et al. 1985). Pillow lavas are scarce within the group, and are present as a roof-pendant within the Craigballyharky intrusion (Fig. 2) (e.g. Angus 1977).

Although exposure is poor, this association of rock types and their field relations strongly supports the view of Hutton et al. (1985) that the Tyrone Plutonic 
144 Group represents the upper parts of a dismembered ophiolite sequence. Previous geochemistry has shown the sequence to be of suprasubduction affinity (Draut et al.

146 2009). Based on a magma-mixing relationship between gabbro and tonalite at

147 Craigballyharky, Hutton et al. (1985) considered the Tyrone Plutonic Group to be

148 contemporaneous with the Tyrone Volcanic Group. A U-Pb zircon $472+2 /-4 \mathrm{Ma}$ age

149 determination of a tonalite from Craigballyharky along with magma relationships was

150 taken as evidence for the age of the ophiolite and for the timing of obduction (Hutton

151 et al. 1985). However, recent U-Pb zircon dating of gabbro from Craigballyharky

152 yielded a significantly older age of $493 \pm 2 \mathrm{Ma}$ for the Tyrone Plutonic Group (Draut

153 et al. 2009) which is discussed later.

154

155

Tyrone Volcanic Group

156 The Tyrone Volcanic Group forms the upper part of the Tyrone Igneous

157 Complex and is comprised of basic to intermediate pillow lavas, volcaniclastic tuffs,

158 rhyolites, banded chert, silica-iron exhalite (ironstone) and argillaceous sediment.

159 The predominant "background" lithology within the Tyrone Volcanic Group is a pale-

160 greenish grey, schistose, chlorite-epidote-sericite tuff, which varies from fine-grained

161 ash to coarse-grained lapilli tuff (Cooper \& Mitchell 2004). Previous research

162 suggests that there is evidence for at least three volcanic cycles within the Tyrone

163 Volcanic Group; each commencing with basaltic lavas, with cycle tops characterised

164 by the presence of laminated chert and/or mudstone at Tanderagee, Bonnety Bush and

165 Broughderg respectively (Hutton et al. 1985; Cooper \& Mitchell 2004). The base of

166 the lowest cycle is represented by the Copney Pillow Lava Formation, with rhyolite at

167 Formil Hill (Fig. 2) taken as the top of cycle two (Cooper \& Mitchell 2004).

168 Biostratigraphical correlation and a robust $\mathrm{U}-\mathrm{Pb}$ zircon age constraint of $473 \pm 0.8 \mathrm{Ma}$

169 from the Formil Hill rhyolite, suggest an age for the upper Tyrone Volcanic Group

170 within the Australasian Castlemainian (Ca1) Stage of the Arenig (Cooper et al. 2008)

171 (Fig. 3).

172

173

174 Volcanic Group. They suggested it formed within an oceanic arc which assimilated

175 considerable detritus from the Laurentian margin and made a correlation with the

176 Lough Nafooey arc of western Ireland. Although Cobbing et al. (1965) considered the

177 Tyrone Volcanic Group to unconformably overlie the Tyrone Central Inlier, both 
178 Harley (1933) and more recent work (Cooper \& Mitchell 2004; Draut et al. 2009)

179 favoured a tectonic contact between the units. Nowhere are contacts exposed with

180 either the Tyrone Plutonic Group or the Tyrone Central Inlier.

181

182

183

184

185

186

187

188

189

190

191

192

193

194

195

196

197

198

199

200

201

202

203

204

205

206

207

208

209

\section{Late Intrusive Rocks}

Several large granitic to tonalitic intrusions cut the Tyrone Igneous Complex and Tyrone Central Inlier (Fig. 2). All show an I-type affinity except an intrusion of muscovite granite at Tremoge Glen. A series of high-level sills and dykes of porphyryitic dacite cut all levels of the complex. Strong large ion lithophile element (LILE) and light rare earth element (LREE) enrichment, coupled with zircon inheritance and strongly negative $\varepsilon \mathrm{Nd}_{(\mathrm{t})}$ values, suggest that assimilation of Dalradianaffinity metasediments was an integral part of their petrogenesis (Draut et al. 2009).

Field relations at Craigballyharky show roof pendants of Ordovician pillow basalt and sheeted dolerite enclosed within tonalite, demonstrating the Tyrone Plutonic Group was in its present structural position prior to intrusion (Cobbing et al. 1965; Angus 1977; GSNI 1979). Granodiorite at Craigbardahessiagh contains pendants of Ordovician volcanic rocks and ironstone, and tonalite from Craigballyharky (Cobbing et al. 1965; Angus 1977; GSNI 1979). Tonalite from Craigballyharky and Leaghan (i.e. Cashel Rock, Fig. 2) has yielded U-Pb zircon ages of $472^{+2} /-4 \mathrm{Ma}$ (Hutton et al. 1985) and $475 \pm 10 \mathrm{Ma}$ (Draut et al. 2009) respectively.

\section{Sampling and Analytical Methods}

\section{Geochemistry}

A range of stratigraphic levels within the Tyrone Volcanic Group were sampled for geochemical analysis, as were key localities from the Tyrone Plutonic Group and several large tonalitic to granitic intrusions. A total of four Tyrone Plutonic Group, nine Tyrone Volcanic Group, and fifteen arc-related intrusive suite samples were analysed for major, trace and rare-earth elements at the British Geological Survey (BGS) in Nottingham. 
210 Major elements were determined for twenty-eight powdered whole-rock samples on

211 fused glass beads by X-ray Fluorescence Spectrometry (XRF). Samples were dried at

$212105^{\circ} \mathrm{C}$ before loss on ignition (LOI) and fusion. LOI was determined after 1 hour at

$2131050{ }^{\circ} \mathrm{C} . \mathrm{Fe}_{2} \mathrm{O}_{3}$ t represents total iron expressed as $\mathrm{Fe}_{2} \mathrm{O}_{3} . \mathrm{SO}_{3}$ represents sulphur

214 retained in the fused bead after fusion at $1200^{\circ} \mathrm{C}$. Trace elements were analysed on

215 pressed powder-pellets by XRF. Rare earth elements were determined by inductively

216 coupled plasma mass spectrometry (ICP-MS); samples were subjected to an

$217 \mathrm{HF} / \mathrm{HClO}_{4} / \mathrm{HNO}_{3}$ attack with residues fused with $\mathrm{NaOH}$ before solutions were

218 combined. Geochemical results are presented in the supplementary publication.

219 Analyses of Draut et al. (2009) have also been included in many of the diagrams

220 presented here.

221

$\underline{\mathrm{U}-\mathrm{Pb} \text { Geochronology }}$

Nine samples were dated by U-Pb TIMS geochronology at the NERC Isotope

224 Geoscience Laboratory. Three samples were collected from the Tyrone Plutonic

225 Group - the layered gabbro at Scalp, pegmatitic gabbro at Black Rock and sheeted

226 dykes from Carrickmore Quarry (Fig. 2), however only the layered gabbros (JTP207)

227 produced sufficient zircon for successful age dating. Eight samples from the arc-

228 related intrusive suite, including tonalite, granodiorite, granite, porphyritic dacite and

229

quartz-monzodiorite yielded abundant zircon suitable for U-Pb TIMS geochronology.

230

Heavy mineral concentrates were obtained at the NERC Isotope Geosciences

232 Laboratory using standard crushing techniques, a Gemini ${ }^{\mathrm{TM}}$ table, modified

233 superpanner, a Frantz LB1 magnetic separator and heavy liquids. Minerals were

234 selected for analysis by hand picking in alcohol under a binocular microscope and

235 either air-abraded or chemically abraded to improve concordance following Krogh

236 (1982) and Mattinson (2005). Chemically abraded zircons were first annealed at 850

$237{ }^{\circ} \mathrm{C}$ for 48 hours prior to partial dissolution in $29 \mathrm{~N} \mathrm{HF}$ at $180{ }^{\circ} \mathrm{C}$ for $12 \mathrm{hrs}$ (McConnell

238 et al. 2009). Dissolutions, spiking and chemical separations follow Krogh (1973)

239 with modifications after Corfu \& Noble (1992). Procedural blanks of MRC prefixed

240 samples ranged from c. $20 \mathrm{pg}$ to $\leq 10 \mathrm{pg} \mathrm{Pb}$ and $<0.5 \mathrm{pg} \mathrm{U}$, whereas sample JTP

241 prefixed samples had procedural blanks of $2 \mathrm{pg} \mathrm{Pb}$ and $0.1 \mathrm{pg} \mathrm{U}$. 
Correction for common $\mathrm{Pb}$, in excess of the laboratory blank, was made using

244 a Stacey \& Kramers (1975) model $\mathrm{Pb}$ composition calculated for the ${ }^{207} \mathrm{~Pb} /{ }^{206} \mathrm{~Pb}$ age

245 of the analyses, with a $2 \%$ error on the compositions propagated through data

246 reduction calculations. Data were either obtained on a VG354 or Thermo Electron

247 Triton using either a Daly detector or SEM respectively. U-Pb Concordia and upper

248 and lower intercept age calculations followed Ludwig $(1998,2003)$ using the decay

249 constants and measurement uncertainties of Jaffey et al. (1971). Uncertainties quoted

250 for isotope ratios and ages in Table 1 are at the $2 \sigma$ level, and all data are plotted with

$2512 \sigma$ error ellipses.

252

254

$\underline{\text { Results }}$

255

256 All samples examined from the Tyrone Igneous Complex have been subjected to low257 grade metamorphism, sub-greenschist to epidote-amphibolite facies and hydrothermal 258 alteration, which has determined the approaches used in the interpretation of the 259 geochemistry. A selection of lithologies identified from the Tyrone Plutonic Group, 260 Tyrone Volcanic Group and late intrusive suite are described in the supplementary 261 publication. Within the upper Tyrone Volcanic Group, volcanogenic base and 262 precious metal mineralization has led to a variety of alteration types, where pervasive 263 chloritic alteration has been overprinted by variably developed sericitic, carbonate and 264 silicic alteration. Intense argillic alteration is well developed within a sub-economic 265 porphyry $\mathrm{Cu}$ deposit at Formil Hill (Leyshon \& Cazalet 1976) (Fig. 2). Primary 266 minerals are rarely well preserved except in late granitic to tonalitic intrusive rocks. across the Tyrone Igneous Complex suggests that the use of mobile elements for 271 whole rock classification and deducing magma affinity will be compromised. In 272 particular, elements such as $\mathrm{SiO}_{2}, \mathrm{Na}_{2} \mathrm{O}, \mathrm{K}_{2} \mathrm{O}, \mathrm{CaO}, \mathrm{MgO}$ and $\mathrm{FeO}$, and the low-field 273 strength elements (LFSE: Cs, Rb, Ba, Sr, U), are considered mobile under these 274 conditions (MacLean 1990). By contrast, $\mathrm{Al}_{2} \mathrm{O}_{3}, \mathrm{TiO}_{2}$, Th, V, Ni, Cr, Co, the high 275 field strength elements (HFSE: Nb, Hf, Ta, Zr, Y, Sc, Ga) and rare earth elements 276 (REE: minus Eu \pm Ce) typically remain immobile (e.g. Pearce \& Cann 1973; Wood 277 1980; MacLean 1990; Rollinson 1993; Barrett \& MacLean 1999). In light of these 
278 results, particular attention is given to the immobile-element geochemistry of the

279 Tyrone Igneous Complex. Although mass change associated with hydrothermal

280 alteration may alter the absolute concentrations of immobile elements, inter-element

281 ratios will remain constant (MacLean 1990).

282

283 Tyrone Plutonic Group:

284 Rocks from the Tyrone Plutonic Group are tholeiitic and basaltic in composition (Fig. 285 4a-c), with positive $\mathrm{Pb}$, negative $\mathrm{Nb}$ and modest Ti anomalies (Fig. 5a). Geochemical 286 signatures are similar to those previously reported by Draut et al. (2009) (Fig 4 and 287 5a) and are typical of basalts generated in a suprasubduction environment (Pearce et 288 al. 1984b; Fig. 4d). Th concentrations are variable ( 1 to 100x primitive mantle), all 289 samples show weak LREE depletion relative to heavy rare earth elements (HREE) 290 (Fig. 5a), and HFSE concentrations are generally less than those of normal mid ocean 291 ridge basalt. Aphanitic basaltic rocks (e.g. MRC343 and MRC340) classify as island292 arc tholeiitic basalts according to Meschede (1986), Wood (1980), Pearce \& Norry 293 (1979) and Pearce \& Cann (1973).

295 Tyrone Volcanic Group:

296 All basalts analysed from the Tyrone Volcanic Group, except those from Bonnety 297 Bush, are LILE- and LREE-enriched with variable negative $\mathrm{Nb}$ anomalies (Fig. 5b). 298 Basalts range from subalkaline (transitional to calc-alkaline) to borderline alkalic in 299 composition (Fig 4a,c), and plot within the enriched-mid ocean ridge basalt (e300 MORB) fields of Wood (1980) and the within-plate/volcanic-arc fields of Meschede 301 (1986) and Pearce \& Norry (1979). Samples from around Mountfield are alkalic, of 302 within-plate affinity, and do not display the classic HFSE depletion of 303 suprasubduction zone magmatism (Draut et al. 2009). Tholeiitic basalt from Bonnety 304 Bush (MRC349) has $\mathrm{Pb}$ and $\mathrm{Nb}$ anomalies typical for arc-related volcanism, yet has 305 low LILE concentrations, limited Ti anomalies and is LREE depleted relative to 306 HREE (Fig. 5c). Immobile element ratios from this locality (e.g. Sc/Y, Ti/Sc, Ti/V, $307 \mathrm{Sm} / \mathrm{Yb}, \mathrm{Th} / \mathrm{Nb}$ and $\mathrm{Zr} / \mathrm{Nb}$ ) are similar to those from the Tyrone Plutonic Group. 308 All rocks of andesitic to rhyolitic composition (Fig. $\mathbf{4 a}$ and $\mathbf{4 b}$ ), except those 310 from Beaghbeg and Bonnety Bush, are subalkaline and transitional to calc-alkaline in 311 nature (Fig. 4c). They are LILE- and LREE-enriched, and have lower HREE 
312 concentrations than associated basalts. Consideration of the data within multi-element

313 variation diagrams (Fig. 5c) suggests they are typical of arc-related volcanism (e.g.

314 negative $\mathrm{Nb}$ anomalies and HFSE depletion). Tholeiitic rhyolitic tuff from Beaghbeg

315 (MRC345) and strongly altered andesitic tuff from Bonnety Bush (MRC348) are

316 unusual within the Tyrone Volcanic Group, in that they display modest LILE

317 enrichment ( $>10 \mathrm{x}$ primitive mantle), and LREE and HREE concentrations around 10x

318 chondrite. Primitive-mantle normalized multi-element variation diagrams show flat to

319 'U' shaped REE profiles (Fig. 5c).

321 Late arc-related Intrusive Rocks:

322 Calc-alkaline, arc-related intrusive rocks cut both the Tyrone Igneous Complex and

323 the Tyrone Central Inlier (Fig. 2). These rocks display geochemical affinities similar

324 to the LILE- and LREE-enriched rhyolites and andesites of the Tyrone Volcanic

325 Group (Fig. 4 and 5b,d), with granitic rocks classified as volcanic-arc granites

326 according to their Ta-Yb systematics (Pearce et al. 1984a).

\section{$\underline{\mathrm{U}-\mathrm{Pb} \text { Geochronology }}$}

Calculated $\mathrm{U}-\mathrm{Pb}$ ages for samples analysed are presented in Table 2, along

330 with additional information. The U-Pb ages (Fig. 6), range in age from $479.6 \pm 1.1$

331 Ma to $464.3 \pm 1.5 \mathrm{Ma}$. All samples display evidence of zircon inheritance. Gabbro

332 from the Tyrone Plutonic Group (JTP207) was dated at 479.6 $\pm 1.1 \mathrm{Ma}$, with inherited

333 ages of c. $1015 \mathrm{Ma}$ and c. $2100 \mathrm{Ma}$. All samples investigated from the arc-related

334 intrusive suite range in age between c. $470 \mathrm{Ma}$ and $464 \mathrm{Ma}$ (Fig. 6). Granite from

335 Slieve Gallion (MRC92, 466.5 $\pm 3.3 \mathrm{Ma}$ ) and granodiorite from Craigbardahessiagh

336 (MRC91, 464.9 $\pm 1.5 \mathrm{Ma}$ ) both contain Mesoproterozoic inherited zircons. Zircons

337 analysed from quartz porphyry (dacite) from Copney (MRC90, $465 \pm 1.7 \mathrm{Ma}$ ) and

338 tonalite from Craigballyharky (MRC128, 470.3 $\pm 1.9 \mathrm{Ma})$ both contain inherited

339 components dated at c. $2100 \mathrm{Ma}$. Our U-Pb zircon age of the tonalite from

340 Craigballyharky is within error of that proposed by Hutton et al. (1985).

\section{Discussion}

344 Using these new U-Pb geochronology and geochemical data we can refine current 345 models for the evolution of the Tyrone Igneous Complex and timing of the Grampian 
346 orogeny within Ireland. Our new tectonic model based around the Tyrone Igneous

347 Complex is presented in Figure 7.

348

349

350

351

352

353

354

355

356

357

358

359

360

361

362

363

364

365

366

367

368

369

370

371

372

373

374

375

376

377

378

\section{Development of the Tyrone Plutonic Group}

Field relationships and geochemical evidence including negative $\mathrm{Nb}$ anomalies and HFSE depletion suggests the Tyrone Plutonic Group represents the uppermost portions of a suprasubduction zone ophiolite which was emplaced onto an outboard segment of Laurentia, the Tyrone Central Inlier, during the Grampian event. Though fault bounded, the Tyrone Plutonic Group and Tyrone Volcanic Group were previously considered contemporaneous based on a magma-mixing relationship between gabbro and $4722^{+2} /{ }_{-4}$ Ma tonalite at Craigballyharky (Hutton et al. 1985). However, recent work by Draut et al. (2009) reported an age of $493 \pm 2 \mathrm{Ma}$ for the Craigballyharky gabbro which is too old considering the magma-mixing relationship observed with c. 470 Ma tonalite (MRC128 at $470.3 \pm 1.9 \mathrm{Ma}$; also $4722^{+2} /{ }_{4}$ Ma of Hutton et al. 1985). The zircon age of $493 \mathrm{Ma}$ derived by Draut et al. is a ${ }^{206} \mathrm{~Pb} /{ }^{238} \mathrm{U}$ age of three reversely discordant analyses. The reverse discordance is a probable analytical artifact of the SIMS data, possibly attributed to high uranium content of the zircons. The mean ${ }^{207} \mathrm{~Pb} /{ }^{206} \mathrm{~Pb}$ age of these same three analyses gives $468 \pm 22 \mathrm{Ma}$ $(2 \sigma)$. Draut et al. (2009) also presented zircon ages from the Craigballyharky gabbro of approximately $470 \mathrm{Ma}$, but disregarded them as sample contamination. These three apparently younger zircons give a mean ${ }^{206} \mathrm{~Pb} /{ }^{238} \mathrm{U}$ age of $473.2 \pm 1.6 \mathrm{Ma}(2 \sigma)$. We therefore propose that the Craigballyharky gabbro, which is LREE-enriched, is considerably younger than that proposed by Draut et al. (2009) and belongs to the arcrelated intrusive (c. 470-464 Ma) suite. This scenario also agrees with the magmamixing relationship observed.

Our new U-Pb zircon age determination from the layered gabbro at Scalp (JTP207, 479.6 $\pm 1.1 \mathrm{Ma}$ ), suggests that formation of the Tyrone Plutonic Group initiated at c. $480 \mathrm{Ma}$ (Fig. 7a). Two inherited grains at c. 1015 and c. 2100 from the Scalp layered gabbro signify that material of this age was present at depth by c. 480 Ma. Their occurrence in the ophiolitic Tyrone Plutonic Group may reflect subduction of peri-Laurentian metasediments under the Tyrone ophiolite during formation. Primitive geochemical characteristics presented herein (JTP207) are 
379

380

381

382

383

384

385

386

387

388

389

390

391

392

393

394

395

396

397

398

399

400

401

402

403

404

405

406

407

408

409

410

411

412

inconsistent with alternate explanations, which would require intrusion of the Scalp gabbro after ophiolite emplacement with xenocrystic zircons derived during emplacement through the Tyrone Central Inlier. As zircons of c. $2100 \mathrm{Ma}$ are not present in abundance in peri-Laurentian sources (Cawood et al. 2007), including the Tyrone Central Inlier (Chew et al. 2008), their occurrence as xenocrysts may signify a difference in age signature of the basement underlying the region at this time.

\section{Emplacement of the Tyrone Plutonic Group}

Obduction of the Tyrone Plutonic Group onto the Tyrone Central Inlier must have occurred prior to $c .470 \mathrm{Ma}$ (Fig. 7b-c). Two intrusions dated here at c. $470 \mathrm{Ma}$ (MRC128, 470.3 $\pm 1.9 \mathrm{Ma}$; MRC126, 469.9 $\pm 2.9 \mathrm{Ma}$ ) cut the Tyrone Plutonic Group in its present structural position upon the Tyrone Central Inlier. At Craigballyharky, tonalite (MRC128) contains roof-pendants of LREE-depleted basalt derived from the Tyrone Plutonic Group. Whole rock and isotope geochemistry (see Draut et al. 2009) and zircon inheritance from these granitic to tonalitic stitching intrusions suggests they ascended through continental crust. Zircon inheritance (MRC128, MRC126) is compatible with derivation from the underlying Tyrone Central Inlier (Chew et al. 2008).

Sillimanite-bearing metamorphic assemblages and leucosomes in paragneisses within the Tyrone Central Inlier are cut by granite pegmatites (Chew et al. 2008). The main fabric of the leucosomes yielded a ${ }^{40} \mathrm{Ar}-{ }^{39} \mathrm{Ar}$ biotite cooling age of $468 \pm 1.4 \mathrm{Ma}$ (Chew et al. 2008), which implies the Tyrone Central Inlier was metamorphosed and deformed under a thick, high-temperature succession prior to $468 \pm 1.4 \mathrm{Ma}$ (c. 670 ${ }^{\circ} \mathrm{C}, 6.8$ kbar of Chew et al. 2008), consistent with ophiolite emplacement prior to $C$. $470 \mathrm{Ma}$ (Fig. 7c). The lack of an ultramafic succession within the Tyrone Plutonic Group may be explained by post-obduction excision. In western Ireland, late extensional detachments associated with the Deep Park ophiolitic mélange juxtapose high-pressure, low-temperature blueschist facies rocks alongside lower-pressure Barrovian metasediments (e.g. Chew et al. 2010).

Rocks of the South Mayo Trough, western Ireland, the fore-arc to the Lough Nafooey arc, record significant quantities of ophiolite-derived sediment entering the basin from c. $478 \mathrm{Ma}$ (Chew 2009); systematic changes in Mg, Cr, Ni (Wrafter \& 
413 Graham 1989) and detrital chrome spinel (Dewey \& Mange, 1999) suggest the

414 progressive unroofing on a ophiolite prior to the exhumation of the Grampian

415 metamorphic belt (Fig. 7a). It is possible that obduction of the Tyrone Plutonic

416 Group was also initiated at or shortly after c. 480 Ma. Evidence from certain

417 ophiolites suggests that the timing of magmatism and obduction may be very closely

418 spaced. For instance, age constraints from the Oman-UAE ophiolite indicate that the

419 latest, seafloor, rift-related magmatism occurred less than 1 m.y. prior to obduction

420 (Styles et al. 2006; Goodenough et al. 2010).

421

422

423

424

425

426

427

428

429

430

431

432

433

434

435

436

437

438

439

440

441

442

443

444

445

\section{Development of the Tyrone Volcanic Group}

Geochemical variation within the Tyrone Volcanic Group is predominantly characterised by transitional to calc-alkaline island-arc signatures, with strong enrichment in the LILE and LREE, high La/Sm and an increasing component of continentally derived material up sequence (see Draut et al. 2009). $\mathrm{Th} / \mathrm{Yb}-\mathrm{Nb} / \mathrm{Yb}$ systematics imply the magmas were similar to eMORB in composition, but enriched in subduction zone components (e.g. Th, Cs, Rb, Ba, Pb). Draut et al. (2009) proposed the observed increase in La/Sm, LILE- and LREE-enrichment, and lowering of $\varepsilon \mathrm{Nd}_{(\mathrm{t})}$ values reflects the approach of the arc to the continental margin, subduction of continental detritus and magmatism during arc-continent collision. Although the strongly negative $\varepsilon \mathrm{Nd}_{(\mathrm{t})}$ values and LILE- and LREE-enrichment within the Tyrone Volcanic Group are also consistent with formation within an ensialic arc, the occurrence of primitive basalt at several stratigraphic horizons and the absence of zircon inheritance within the $c .473$ Formil rhyolite (the only the only dated sample which sensu stricto belongs to the Tyrone Volcanic Group, Cooper et al. 2008), , suggest an oceanic-affinity for the Tyrone arc.

Tholeiitic rhyolite and silicified andesite from Beaghbeg and Bonnety Bush are unusual within the Tyrone Volcanic Group in that they display flat to 'U-shaped' chondrite-normalized REE profiles. Although boninite sensu stricto was not recorded within the samples analysed, tholeiitic rhyolites with U-shaped REE profiles, which typically form from the melting of mafic (to andesitic) substrates, are present, and are similarly often associated with forearc rifting, intra-arc rifting or rifting during the initiation of back-arc basin activity (see. Piercey 2007). These lavas 
446 stratigraphically overly the $473 \pm 0.8$ Ma rhyolite of Cooper et al. (2008) and are

447 closely associated with primitive tholeiitic and LREE-depleted island-arc basalt from

448 Bonnety Bush. If the tholeiitic rhyolites of Beaghbeg mark the initiation of intra-arc

449 rifting, then the LREE-depleted basalts of Bonnety Bush are a likely consequence of

450 the same process, representing eruption onto the floor of the newly formed basin.

451

452 borderline alkalic, of within-plate affinity, lacks the prominent HFSE depletion of subduction-related magmatism, and displays weakly positive $\varepsilon \mathrm{Nd}_{(\mathrm{t})}$ values. Draut et al. (2009) suggested this basalt formed at a late stage in the orogen when no strong underthrusting occurred, and is perhaps associated with a reversal in subduction polarity and/or gravitationally induced loss of the lower crust. Although the Mountfield basalts are geochemically consistent with formation in a seamount, their close association with strongly LILE- and LREE enriched rhyolite, argillaceous sediment, abundant volcaniclastic tuff and chert makes this unlikely.

Correlatives across the Grampian - Taconic orogen by $499 \pm 8 \mathrm{Ma}$, with high-grade obduction-related metamorphism constrained to $c$. $490 \pm 4 \mathrm{Ma}$ (Chew et al. 2010). Similarly, in western Ireland high-grade metamorphism was underway by $514 \pm 3$ Ma prior to exhumation at $482 \pm 1 \mathrm{Ma}$ (Deer Park Complex: Chew et al. 2010). Together these dates suggest a correlation between these ophiolites and the c. 510-501 Ma Lushs Bight Oceanic Tract of Newfoundland. As the Highland Border and Deerpark Complex ophiolites experienced metamorphism and deformation at least 15 m.y. before the Grampian event (c. 475-465 Ma), Chew et al. (2010) suggested early obduction may have occurred substantially outboard of the Laurentian margin onto peri-Laurentian microcontinental blocks.

Following obduction, a primitive oceanic-arc, represented locally by the Lough Nafooey and Tourmakeady Groups of western Ireland (Lough Nafooey arc), was active by c. $490 \mathrm{Ma}$ (Chew et al. 2010) (Fig. 7a). Granitoid boulders of this age indicate the assimilation of crustal material $\left(\varepsilon_{\mathrm{Nd}_{(\mathrm{t})}} \sim 0\right.$, Chew et al. 2007). This 
480 ophiolite - oceanic arc complex is preserved within Newfoundland as the c. $490 \mathrm{Ma}$

481 Baie Verte Oceanic Tract and the overlying c. 487-476 Ma oceanic Snooks Arm

482 arc/back-arc (see van Staal et al. 2007). Collision between the Lough Nafooey arc

483 and the Laurentian margin occurred at c. $478 \mathrm{Ma}$ (Fig. 7b). The Tourmakeady Group

484 (c. 478-470) records volcanism during peak deformation and regional metamorphism

485 within the Dalradian Supergroup (Draut et al. 2004).

486

487

488

489

490

Similar ages for the Tyrone Plutonic Group (479.6 $\pm 1.1 \mathrm{Ma})$ have been reported from the Ballantrae Complex of Scotland (e.g. $483 \pm 4$ Ma, Bluck et al. 1980 ) and the Annieopsquotch ophiolite belt of Newfoundland (481 to $478 \mathrm{Ma}$,

491 outboard of the Tyrone Central Inlier suggests temporal correlation to the

492 Annieopsquotch ophiolite belt, although all components of the Annieospquotch

493 Accretionary Tract were progressively underplated to the Dashwoods microcontinent

494 above a west-dipping subduction zone (Zagorevski et al. 2009). As contacts between

495 the Tyrone Plutonic Group, Tyrone Volcanic Group, and Tyrone Central Inlier are

496 unexposed it remains unclear exactly how the Tyrone Igneous Complex was

497 obducted.

498

499 Similarly, it is at present unclear whether the Tyrone Volcanic Group (and Tyrone

500 Plutonic Group) developed above a north- or south-dipping subduction zone; both are

501 plausible. In the former case, correlation to the Lough Nafooey arc of western Ireland

502 would be permitted, as suggested by Draut et al. (2009) and shown in Figure 7.

503 Current geochronology from the Tyrone Volcanic Group, although limited, is

504 consistent with correlation either to the Tourmakeady Group of western Ireland (the

505 syn-collisional stage of the Nafooey arc, also see Draut et al. 2009), or the Buchans

506 Group and correlative Roberts Arm Group of the Anniopsquotch Accretionary Tract

507 (see Zagorevski et al. 2009). Both the Buchans arc and its continental basement were

508 accreted to the Dashwoods microcontinent prior to c. $468 \mathrm{Ma}$ accompanied by the

509 intrusion of dominantly arc-like continental plutons within the Annieopsquotch

510 Accretionary Tract and adjacent Notre Dame Arc (Lissenberg et al. 2005). This

511 intrusive suite is comparable in age to those seen in Tyrone (c. 470-464 Ma),

512 Connemara (Cliff et al. 1996; Friedrich et al. 1999; McConnell et al. 2009) and also

513 those intruding the NE Ox Mountains Slishwood Division (Flowerdew et al. 2005). 
514 Future lithogeochemistry and U-Pb geochronology may shed further light on the

515 development of this enigmatic arc system.

516

\section{Conclusions}

The U-Pb geochronology and geochemistry presented herein refine current

520 models of formation for the Tyrone Igneous Complex and the Grampian orogenic

521 system within the British and Irish Caledonides. Geochemical variation within the

522 Tyrone Plutonic Group is typical for a suprasubduction zone ophiolite and our new U-

$523 \mathrm{~Pb}$ zircon age of $479.6 \pm 1.1$ Ma constrains the timing of development of the Tyrone

524 Plutonic Group. Obduction onto the Tyrone Central Inlier must have occurred prior to

$525470.3 \pm 1.9 \mathrm{Ma}$, although this may have been initiated as early as c. 480-478 Ma. The

526 presence of xenocrystic c. 2100 and 1500 Ma zircons in the Scalp layered gabbro may

527 signify a difference in age signature of the basement underlying the region.

Geochemical analyses of the Tyrone Volcanic Group indicates that it formed

530 within an oceanic volcanic arc receiving an increasing component of continentally

531 derived material from the Laurentian margin. Magmatism associated with the

532 maturing arc is strongly LILE- and LREE-enriched and calc-alkaline in nature.

533 Tholeiitic rhyolites with U-shaped REE profiles and LREE-depleted basalts mark the

534 initiation and formation of an intra-arc basin at c. 475 Ma. Arc-continent collision

535 can be constrained to $c .470 \mathrm{Ma}$ in Northern Ireland. Eight new U-Pb ages from the

536 arc-related intrusive suite range from $470.3 \pm 1.9$ to $464.9 \pm 1.5 \mathrm{Ma}$ and are associated

537 with continued closure of the Iapetus Ocean.

\section{Acknowledgements}

540 This work was made possible through a combination of Northern Ireland government

541 Department of Enterprise Trade and Investment and Northern Ireland Environment

542 Agency funding. Our sincere thanks go to John Cobbing (British Geological Survey -

543 BGS) and Terry Johnston (Geological Survey of Northern Ireland - GSNI) for

544 assistance during initial project scoping sample collection and for sharing their

545 detailed field knowledge of the Tyrone Igneous Complex. Bernard Bingen, two

546 anonymous journal reviewers and BGS reviewers Kathryn Goodenough and Michael 
547 Young (BGS) are acknowledged for improving the manuscript. We thank Sandy

548 Archibald (Aurum Exploration Services) for project inputs and ideas. Mark Allen and 549 staff (BGS) are thanked for geochemical sample preparation and analysis. At NIGL,

550 Adrian Wood is thanked for preparing the heavy mineral separates and Karine David,

551 Craig Storey, Neil Boulton and Aaran Sumner are thanked for technical support for

$552 \mathrm{U}-\mathrm{Pb}$ dating. MRC, SRN and RJM publish with permission of the Executive Director

553 of the BGS (NERC). SPH gratefully acknowledges funding from the BGS University

554 Funding Initiative, Dalradian Resources, GSNI, University of Southampton, Metallum

555 Resources and Natural History Museum, London.

556

557 References

558 Angus, N.S. 1977. The Craigballyharkey Granitic Complex within the Tyrone

559 Igneous Series. Proceedings of the Royal Irish Academy, 77, B, 181-199.

560 BARRETT, T.J., \& MACLEAN, W.H. 1999. Volcanic sequences, lithogeochemistry, and

561 hydrothermal alteration in some bimodal volcanic-associated massive sulfide

562 systems. In Barrie, C.T. \& Hannington, D. (eds) Volcanic-associated massive

563 sulfide deposits: processes and examples in modern and ancient environments.

564 Society of Economic Geologists, Reviews in Economic Geology, 8, 101-131.

565 Bluck, B.J., Halliday, A.N., Aftalion, M. \& Macintyre, R.M. 1980. Age and

566 origin of the Ballantrae ophiolite and its significance to the Caledonian orogeny

567 and Ordovician time scale. Geology, 8, 492-495.

568 Cawood, P.A., Nemchin, A.A., Strachan, R., Prave, T. \& Krabbendam, M.

5692007 . Sedimentary basin and detrital zircon record along East Laurentia and

570 Baltica during assembly and breakup of Rodinia. Journal of the Geological

571 Society, London, 164, 257-275.

572 Chew, D.M. 2009. Grampian Orogeny. In Holland, C.H. \& Saunders, I.S. (eds)

573 The Geology of Ireland, second edition, Dunedin Academic Press, 69-93.

574 Chew, D.M., Graham, J.R. \& Whitehouse, M.J. 2007. U-Pb zircon geochronology

575 of plagiogranites from the Lough Nafooey (= Midland Valley) arc in western

576 Ireland: constraints on the onset of the Grampian orogeny. Journal of the

577 Geological Society, London, 164, 747-750.

578 Chew, D.M., Flowerdew, M.J., Page, L.M., Crowley, Q.G., Daly, J.S., CoOPer,

579 M. R. \& Whitehouse, M.J. 2008. The tectonothermal evolution and provenance

580 of the Tyrone Central Inlier, Ireland: Grampian imbrication of an outboard 
581

582

583

584

585

586

587

588

589

590

591

592

593

594

595

596

597

598

599

600

601

602

603

604

605

606

607

608

609

610

611

612

613

614

Laurentian microcontinent? Journal of the Geological Society, London, 165, 675685.

Chew, D.M., Daly, J.S., Magna, T., Page, L.M., Kirkland, C.L., Whitehouse, M.J., LAM, R. 2010. Timing of ophiolite obduction in the Grampian orogen. GSA Bulletin, 122, 1787-1799.

ClifF, R.A., YARDLEY, B.W.D., \& Bussy, F. 1996. U-Pb and Rb-Sr geochronology of magmatism and metamorphism in the Dalradian of Connemara, W. Ireland. Journal of the Geological Society, London, 153, 109-120.

Clift, P.D., \& RYAN, P.D. 1994. Geochemical evolution of an Ordovician island arc, South Mayo, Ireland. Journal of the Geological Society, London, 151, 329-342.

CoBbing, E.J., MANNING, P.I. \& GRIFFITH, A.E. 1965. Ordovician-Dalradian unconformity in Tyrone. Nature, 206, 1132-50.

CoOper, M.R., \& Mitchell, W.I. 2004 Midland Valley Terrane. In Mitchell, W.I. (ed) The Geology of Northern Ireland. Our Natural Foundation, second edition. Geological Survey of Northern Ireland.

CoOper, M.R., Crowley, Q.G. \& Rushton, A.W. A. 2008. New age constraints for the Ordovician Tyrone Volcanic Group, Northern Ireland. Journal of the Geological Society, London, 165, 333-339.

Corfu, F. \& Noble, S.R. 1992. Genesis of the southern Abitibi greenstone belt, Superior Province, Canada: Evidence from zircon Hf-isotope analyses using a single filament technique. Geochimica et Cosmochimica Acta, 56, 2081-2097.

Dewey, J.F. 2005. Orogeny can be very short. Proceedings of the National Academy of Sciences of the United States of America, 102(43), 15286-15293.

Dewey, J.F. \& Mange, M.A. 1999. Petrography of Ordovician and Silurian sediments in the western Irish Caledonides: tracers of a short-lived Ordovician continent-arc collision orogeny and the evolution of the Laurentian AppalachianCaledonian margin. In MacNiocaill, C. \& Ryan, P.D. (eds) Continental Tectonics. Geological Society of London, Special Publication, 164, 55-107.

DEWEY, J.F. \& RYAN, P.D. 1990. The Ordovician evolution of the South Mayo Trough, western Ireland. Tectonics, 9, 887-901.

DeWEy, J.F. \& SHACKLETON, R.M. 1984. A model for the evolution of the Grampian tract in the early Caledonides and Appalachians. Nature, 312, 115-121.

Draut, A.E., Clift, P.D., Chew, D.M., CoOper, M.J., TAYlor, R.N., \& Hannigan, R.E. 2004. Laurentian crustal recycling in the Ordovician Grampian Orogeny: 
$615 \quad \mathrm{Nd}$ isotopic evidence from western Ireland. Geological Magazine, 114(2), 195-

616207.

617 Draut, A.E., Clift, P.D., Amato, J.M., Blusztajn, J. \& Schouten, H., 2009. Arc-

618 continent collision and the formation of continental crust: a new geochemical and

619 isotopic record from the Ordovician Tyrone Igneous Complex, Ireland. Journal of

620 the Geological Society, London, 166, 485-500.

621 Dunning, G.R., \& KROGH, T.E. 1985. Geochronology of ophiolites of the

622 Newfoundland Appalachians. Canadian Journal of Earth Sciences, 22, 1659-

$623 \quad 1670$.

624 Flowerdew, M.J., DALY, S., \& Whitehouse M.J. 2005. 470 Ma granitoid

625 magmatism associated with the Grampian Orogeny in the Slishwood Division,

626 NW Ireland. Journal of the Geological Society, London, 162, 563-575.

627 Flowerdew, M.J., Chew, D.M., DALY, J.S \& Millar, I.L. (2009) Hidden Archaean

628 and Palaeoproterozoic crust in NW Ireland? Evidence from zircon Hf isotope data

629 from granitoid intrusions. Geological Magazine, 146, 903-916.

630 Friedrich, A.M., Hodges, K.P., Bowring, S.A., \& Martin, M.W. 1999.

631 Geochronological constraints on the magmatic, metamorphic and thermal

632 evolution of the Connemara Caledonides, western Ireland. Journal of the

633 Geological Society, London, 156, 1217-1230.

634 Geological Survey of Northern Ireland. 1979. Pomeroy, Northern Ireland

635 Sheet 34. Solid. 1:50,000. (Southampton: Ordnance Survey for the Geological

636 Survey of Northern Ireland).

637 Geological Survey of NorThern IRELAND. 1983. Cookstown, Northern Ireland

638 Sheet 27. Solid. 1:50,000. (Southampton: Ordnance Survey for the Geological

639 Survey of Northern Ireland).

640 Geological SurVey OF Northern IREland. 1995. Draperstown. Northern Ireland

641 Sheet 26. Solid and Drift Geology. 1:50,000. (Keyworth, Nottingham: British

642 Geological Survey).

643 Goodenough, K.M., Styles M.T., Schofield D., Thomas R.J., Crowley Q.G.,

644 Lilly R.M., McKervey, J., Stephenson, D. \& CARNEY, J. 2010. Architecture of

645 the Oman - UAE Ophiolite: evidence for a multi-phase magmatic history, Arabian

646 Journal of Geosciences, 3, 439-458.

647 HARTLEY, J.J. 1933 The geology of north-eastern Tyrone and the adjacent portions of

648 County Londonderry. Proceedings of the Royal Irish Academy, 41B, 218-85. 
649

650

651

652

653

654

655

656

657

658

659

660

661

662

663

664

665

666

667

668

669

670

671

672

673

674

675

676

677

678

679

680

681

Hastie, A.R., Kerr, A.C., Pearce, J.A., \& Mitchell, S.F. 2007. Classification of altered volcanic island arc rocks using immobile trace elements: development of the Th-Co discrimination diagram. Journal of Petrology, 48, 2341-2357.

Hutton, D.H.W., Aftalion, M. \& Halliday, A.N. 1985. An Ordovician ophiolite in County Tyrone, Ireland. Nature, 315, 210-212.

Jaffey, A.H., FlynN, K.F., Glendenin, L.E., Bentley, W.C. \& Essling, A.M. 1971. Precision measurements of half-lives and specific activities of $235 \mathrm{U}$ and 238U. Physics Reviews, C4, 1889-1906.

KROGH, T.E. 1973. A low contamination method for the hydrothermal decomposition of zircon and extraction of $\mathrm{U}$ and $\mathrm{Pb}$ for isotopic age determinations. Geochimica et Cosmochimica Acta, 37, 485-494.

KROGH, T.E. 1982. Improved accuracy of $\mathrm{U}-\mathrm{Pb}$ zircon ages by the creation of more concordant systems using an air-abrasion technique. Geochimica et Cosmochimica Acta, 46, 637-649.

LEYSHON, P.R. \& CAZALET, P.C.D. 1976. Base-metal exploration programme in Lower Palaeozoic volcanic rocks, Co. Tyrone, Northern Ireland. Institution of Mining and Metallurgy, 85, B91-B99.

Lissenberg, C.J., Zagorevski, A., McNicoll, V.J., van StaAl, C.R., \& Whalen, J.B. 2005. Assembly of the Annieopsquotch Accretionary Tract, Newfoundland Appalachians: Age and geodynamic constraints from syn-kinematic intrusions. Journal of Geology, 113, p553-570.

LUDWIG, K.R. 1998. On the treatment of concordant uranium-lead ages. Geochimica et Cosmochimica Acta, 62, 665-676.

LUDWIG, K.R. 2003. Isoplot/Ex version 2.06. A Geochronological toolkit for Microsoft Excel. Berkeley Geochronology Center Special Publication, No.4, 70p.

MATtinson, J. M. 2005. Zircon U-Pb chemical abrasion ("CA-TIMS") method: Combined annealing and multi-step partial dissolution analysis for improved precision and accuracy of zircon ages. Chemical Geology, 220, 47-66.

MaCLEAN, W.H. 1990. Mass change calculations in altered rock series. Mineralium Deposita, 25, 44-49.

McConnell, B., Riggs, N., \& CROwley, Q.G. 2009. Detrital zircon provenance and Ordovician terrane amalgamation, western Ireland. Journal of the Geological Society, London, 166(3), 473-484. 
682 Meschede, M. 1986. A method of discriminating between different types of mid-

683 ocean ridge basalts and continental tholeiites with the Nb-Zr-Y diagram.

684 Chemical Geology, 56, 207-218.

685 Parnell, J., Earls, G., Wilkinson, J.J., Hutton, D.H.W., Boyce, A.J., FAllick, E., 686 Ellam, R.M., Gleeson, S.A., Moles, N.R., Carey, P.F., \& LegG, I. 2000.

687 Regional fluid flow and gold mineralization in the Dalradian of the Sperrin 688 Mountains, Northern Ireland. Economic Geology, 95, 1389-1416.

689 PEARCE, J.A. 1983. Role of the sub-continental lithospehere in magma genesis at 690 active continental margins. In Hawkesworth (ed). Continental basalts and mantle 691 xenoliths. Shiva, Nantwich, 230-249.

692 PEARCE, J.A. 1996. A user's guide to basalt discrimination diagrams. Geological 693 Association of Canada Short Course Notes, 12, 79-113.

694 PEARCE, J.A., \& CANN, J.R. 1973. Tectonic setting of basic volcanic rocks determined 695 using trace element analyses. Earth and Planetary Science Letters, 19, 290-300.

696 Pearce, J.A. \& Norry, M.J. 1979. Petrogenetic implications of Ti, Zr, Y and Nb 697 variations in volcanic rocks. Contributions to Mineralogy and Petrology, 69, 3369847.

699 Pearce, J.A., Harris, N.B.W., \& Tindle, A.G. 1984a. Trace element discrimination 700 diagrams for the tectonic interpretation of granitic rocks. Journal of Petrology, 25, $701956-983$.

702 PeARCE, J.A., LiPPARD. S.J., \& RoBERTS, S. 1984b. Characteristics and tectonic 703 significance of suprasubduction zone ophiolites. In Gass, I.G., Lippard., S.J. \& 704 Shelton, A.W. (eds) Ophiolites and Oceanic Lithosphere. Geological Society, 705 London, Special Publications, 16, 77-94.

706 PIERCEY, S.J. 2007. An overview of the use of petrochemistry in regional exploration 707 for volcanogenic massive sulfide (VMS) deposits. In Milkereit, B. (ed)

708 Proceedings of Exploration 07: Fifth Decennial International Conference on 709 Mineral Exploration, 223-246.

710 Pollock, J.C., HibBard, J.P. \& SYlvester, P.J. 2009. Early Ordovician rifting of 711 Avalonia and birth of the Rheic Ocean: U-Pb detrital zircon constraints from 712 Newfoundland. Journal of the Geological Society of London, 166, 501-515. 713 RyAn, P.D., Floyd, P.A. \& ARChER, J.B. 1980. The stratigraphy and petrochemisty 714 of the Lough Nafooey Group (Tremadocian), western Ireland. Journal of the 715 Geological Society of London, 137, 443-458. 
716 Ryan, P.D., SAWAL, V.K. \& RowlandS, A.S. 1983. Ophiolitic mélange separates

717 ortho- and para-tectonic Caledonides in western Ireland. Nature, 302, 50-52.

718 Rollinson, H.R. 1993. Using geochemical data: evaluation, presentation,

719 interpretation. Longman Group, U.K., Ltd. Harlow, U.K.

720 SAdLer, P.M. CoOPER, R.A., \& Melchin, M. 2009. High-resolution, early Paleozoic

721 (Ordovician-Silurian) time scales. GSA Bulletin, 121, 887-906.

722 Stacey, J.S. \& KRAmERS, J.D. 1975. Approximation of terrestrial lead isotope

723 evolution by a two-stage model. Earth and Planetary Science Letters, 26, 207-

724221.

725 Styles, M, Ellison, R. Arkley, S., Crowley, Q.G., FArRant, A., Goodenough,

726 K.M., McKervey, J, Pharaoh, T., Phillips, E., Schofield, D. \& ThOMAs, R.J.

727 The geology and geophysics of the United Arab Emirates : Volume 2, Geology.,

728 Abu Dhabi, United Arab Emirates, United Arab Emirates, Ministry of Energy,

729 Petroleum and Minerals, 2006, 1-351.

730 Sun, S.-S., \& MCDonOUgh, W.F. 1989. Chemical and isotopic systematics of oceanic

731 basalts: implications for mantle composition and processes. In Saunders, A.D. \&

732 Norry, M.J. (eds) Magmatism in the Ocean Basins. Geological Society, London,

733 Special Publications, 42, 313-345.

734 TAnner, P.W.G. 2007. The role of the Highland Border ophiolite in the $\sim 470 \mathrm{Ma}$

735 Grampian event, Scotland. Geological Magazine, 144, 597-602.

736 Van StaAl, C. R., Dewey, J. F., Mac Niocaill, C. \& McKerrow, W. S. 1998. The

737 Cambrian-Silurian tectonic evolution of the northern Appalachians and British

738 Caledonides: history of a complex, west and southwest Pacific-type segment of

739 Iapetus. In Blundell, D.J. \& Scott, A. C. (eds) Lyell: The Past is the Key to the

740 Present. Geological Society, London, Special Publications, 143, 199-242.

741 Van Staal, C.R., Whalen, J.B., McNicoll, V.J., Pehrsson, S.J., Lissenberg, C.J.,

742 Zagorevski, A., Van Breeman, O., \& Jenner, G.A. 2007. The Notre Dame arc

743 and the Taconic Orogeny in Newfoundland. In Hatcher, J., Carlson, M.P.,

744 McBride, J.H. \& Martínez Catalán, J.R. (eds). The 4D framework of continental

745 crust. Geological Society of America, Memoirs, 200, 511-552.

746 Williams, H., Colman-SadD, S.P., \& Swinden, H.S. 1988. Tectonostratigraphic

747 subdivisions of central Newfoundland. Geological Survey of Canada, Current

748 Research, Part B, Paper 88-1b. 
749 WinCHESTER, J.A., \& FLOYD, P.A. 1977. Geochemical discrimination of different

750 magma series and their differentiation products using immobile elements.

$751 \quad$ Chemical Geology, 20, 325-343.

752 WooD, D.A. 1980. The application of a Th-Hf-Ta diagram to problems of

753 tectonomagmatic classification and to establishing the nature of crustal

754 contamination of basaltic lavas of the British Tertiary volcanic province. Earth

755 and Planetary Science Letters, 50, 11-30.

756 Wrafter, J.P. \& GRAHAM, J.R. 1989. Ophiolitic detritus in the Ordovician sediments

757 of South Mayo, Ireland. Journal of the Geological Society of London, 146, 213-

$758 \quad 215$.

759 Zagorevski, A., Lissenberg, C.J., \& VAN StaAl. 2009. Dynamics of accretion of 760 arc and backarc crust to continental margins: Inferences from the Anniopsquotch 761 accretionary tract, Newfoundland Appalachians. Tectonophysics, 479, 150-164. 762 


\section{Figure Captions}

2

3 Fig. 1 (a) Setting of the Tyrone Igneous Complex and other comparable ophiolite and volcanic arc associations in Britain and Ireland (after Hutton et al. 1985; Parnell et al. 2000: Chew et al. 2008). (b) Simplified regional geology of Newfoundland (after van Staal et al. 2007) (c) Early Mesozoic restoration of North Atlantic region and Appalachian-Caledonian orogen (after Pollock et al. 2009).

Fig. 2. Simplified geological map of the Tyrone Igneous Complex showing locations sampled or discussed in this study (after GSNI, 1979, 1983, 1995). Crosses and plus symbols mark sample locations of Draut et al. (2009) and the new analyses presented here. Copney Pillow Lava Formation and Rhyolite are divisions within the Tyrone Volcanic Group.

Fig. 3. Tectonostratigraphic evolution of the Tyrone Igneous Complex during the Ordovician. Stratigraphy after Cooper \& Mitchell (2004), Cooper et al. (2008); Draut et al. (2009). The standard British Ordovician stages and the Australian graptolite zones are after Sadler et al. (2009). Biostratigraphic and U-Pb zircon ages: 1. Ca1 graptolite age of Cooper et al. (2008); 2. Formil Hill rhyolite of Cooper et al. (2008); 3. Scalp layered gabbro; 4. Laght Hill tonalite; 5. Pomeroy granite ; 6. Copney quartz porphyry; 7. Craigbardahessiagh granodiorite; 8. Slieve Gallion granite; 9. Golan Burn tonalite; 10. Cregganconroe quartz-monzodiorite; 11. Craigballyharky tonalite.

Fig. 4. Geochemical analyses from the Tyrone Igneous Complex; data of Draut et al. (2009) also included. Figure 4a Nb/Y v Zr/Ti after Winchester \& Floyd (1977) modified by Pearce (1996). Figure 4b Th-Co plot after Hastie et al. (2007). Figure 4c Zr v Y after Barrett and MacLean (1999). Figure 4d Th/Yb v Nb/Yb after Pearce (1983). Calc-alk, calc-alkaline; e-MORB, enriched mid-ocean ridge basalt; MORB, mid-ocean ridge basalt; OIB, ocean-island basalt, IAT, island arc tholeiite; SHO, shonshonite.

Fig. 5. Multi-element variation diagrams for samples from the Tyrone Plutonic Group (Fig. 5a), Tyrone Volcanic Group (Fig. 5b,c) and arc-related intrusives (Fig. 5d). 
34 Shading reflects Draut et al. (2009) data for each respective group. Primitive mantle normalization values after Sun and McDonough (1989).

Fig. 6. ${ }^{206} \mathrm{~Pb} /{ }^{238} \mathrm{U}_{-}{ }^{207} \mathrm{~Pb} /{ }^{235} \mathrm{U}$ concordia diagrams: (a) JTP207 Scalp layered gabbro. (b) JTP209 Laght Hill tonalite. (c) MRC89 Pomeroy granite. (d) MRC90 Copney quartz porphyry. (e and f) MRC91 Craigbardahessiagh granodiorite. (g and h) Slieve

40 Gallion granite. (i) MRC126 Golan Burn tonalite. (j) MRC127 Cregganconroe

41 quartz-monzodiorite. (k) Craigballyharky tonalite, with data of Hutton et al. (1985)

42 also shown. All data-point error ellipses are $2 \sigma$.

Fig. 7. Tectonic model for the formation of the Tyrone Igneous Complex during the early Ordovician, illustrating contrasts with the NafooeyTourmakedy arc system of western Ireland. (a) Ophiolite exhumation in western Ireland occurs at c. $480 \mathrm{Ma}$, around the same time as maturation of the Nafooey arc and formation of the Tyrone Plutonic Group. (b) Formation of the Tyrone Volcanic Group occurs between $>c .475 \mathrm{Ma}$ and $470 \mathrm{Ma}$, synchronous

50 with arc-continent collision in western Ireland and development of the

51 Tourmakeady Group. (c) Subduction polarity reversal in western Ireland

52 occurs prior to c. 464 Ma. In Northern Ireland, arc-continent collision occurs

53 prior to the intrusion of a suite of c. 470-464 Ma continental intrusives. Ages

54 after Draut et al. (2004). Dewey (2005), Cooper et al. (2008), Chew et al.

55 (2008, 2010). C.B.C, Clew Bay Complex; L.N.A, Lough Nafooey arc; S.M.T, 56 South Mayo Trough; T.P.G, Tyrone Plutonic Group; T.V.G, Tyrone Volcanic 57 Group. 


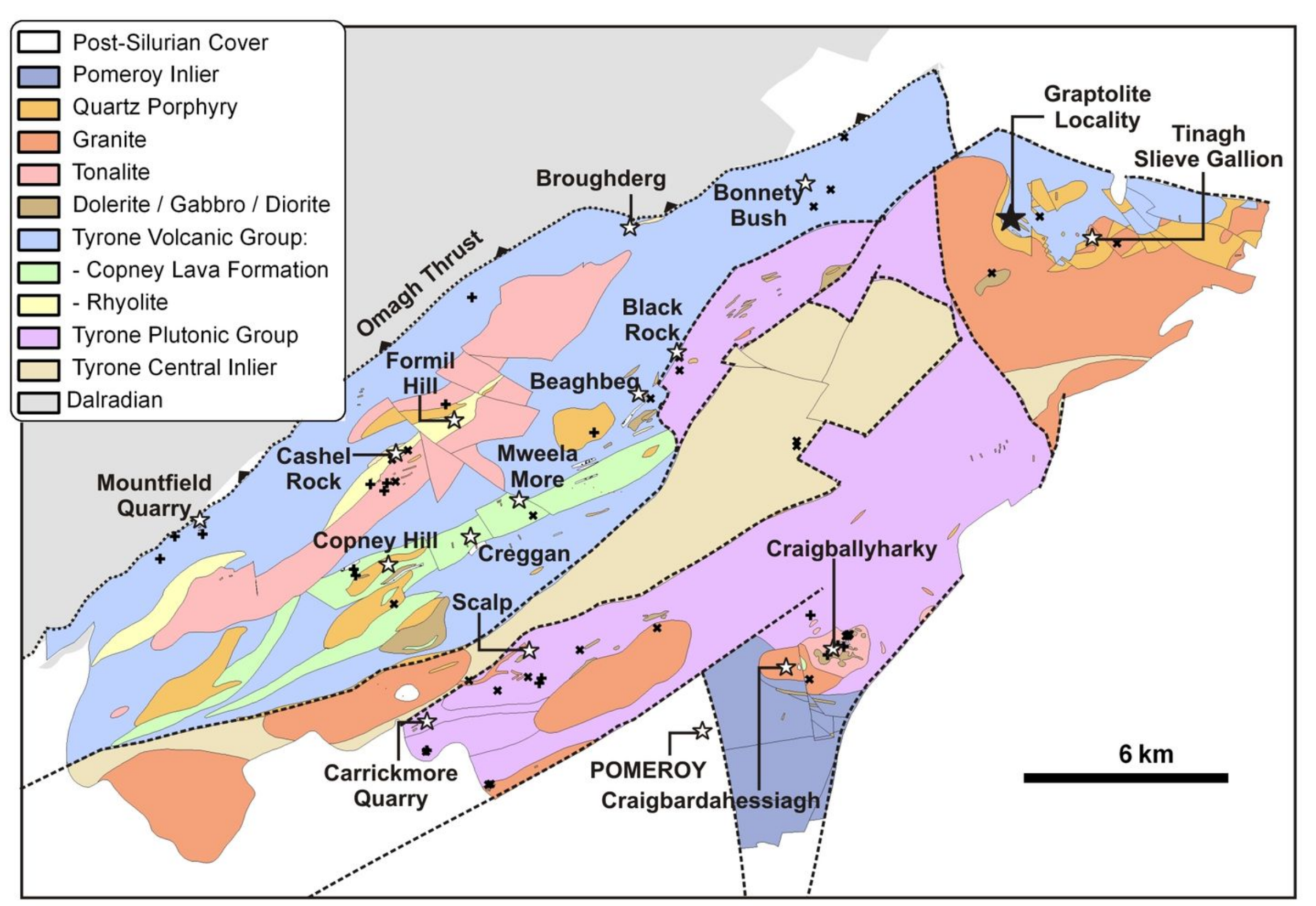




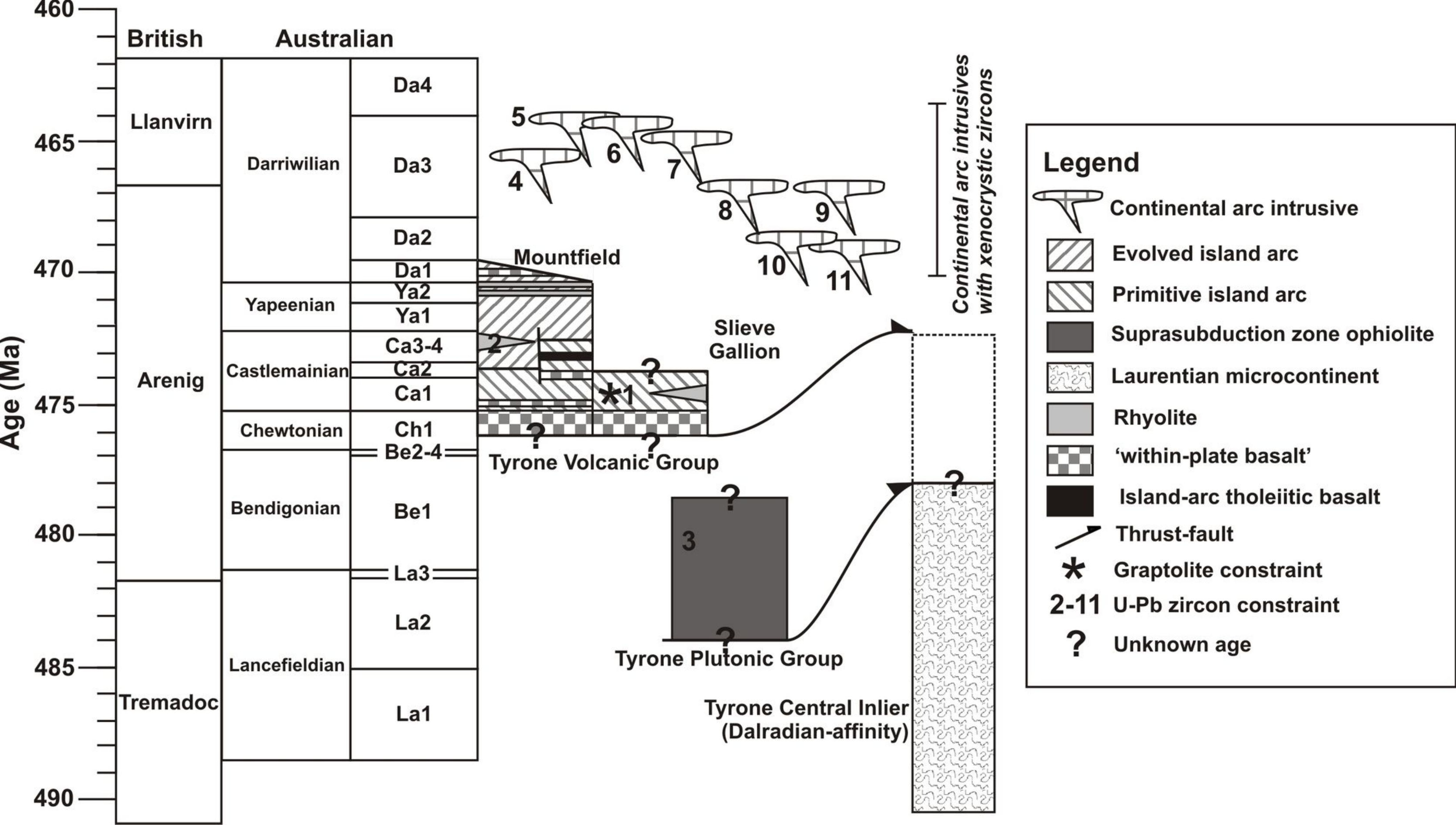



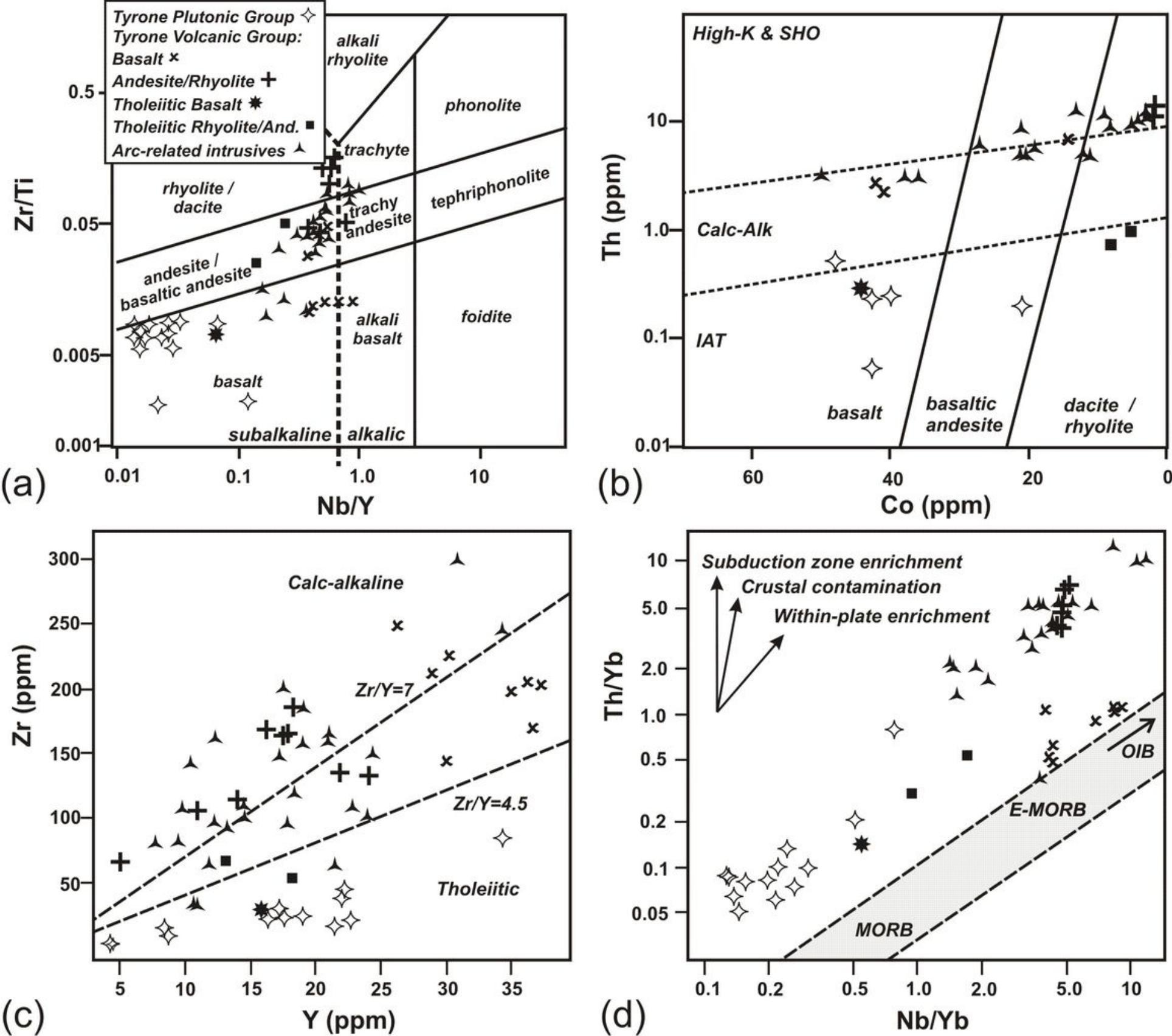
(a)
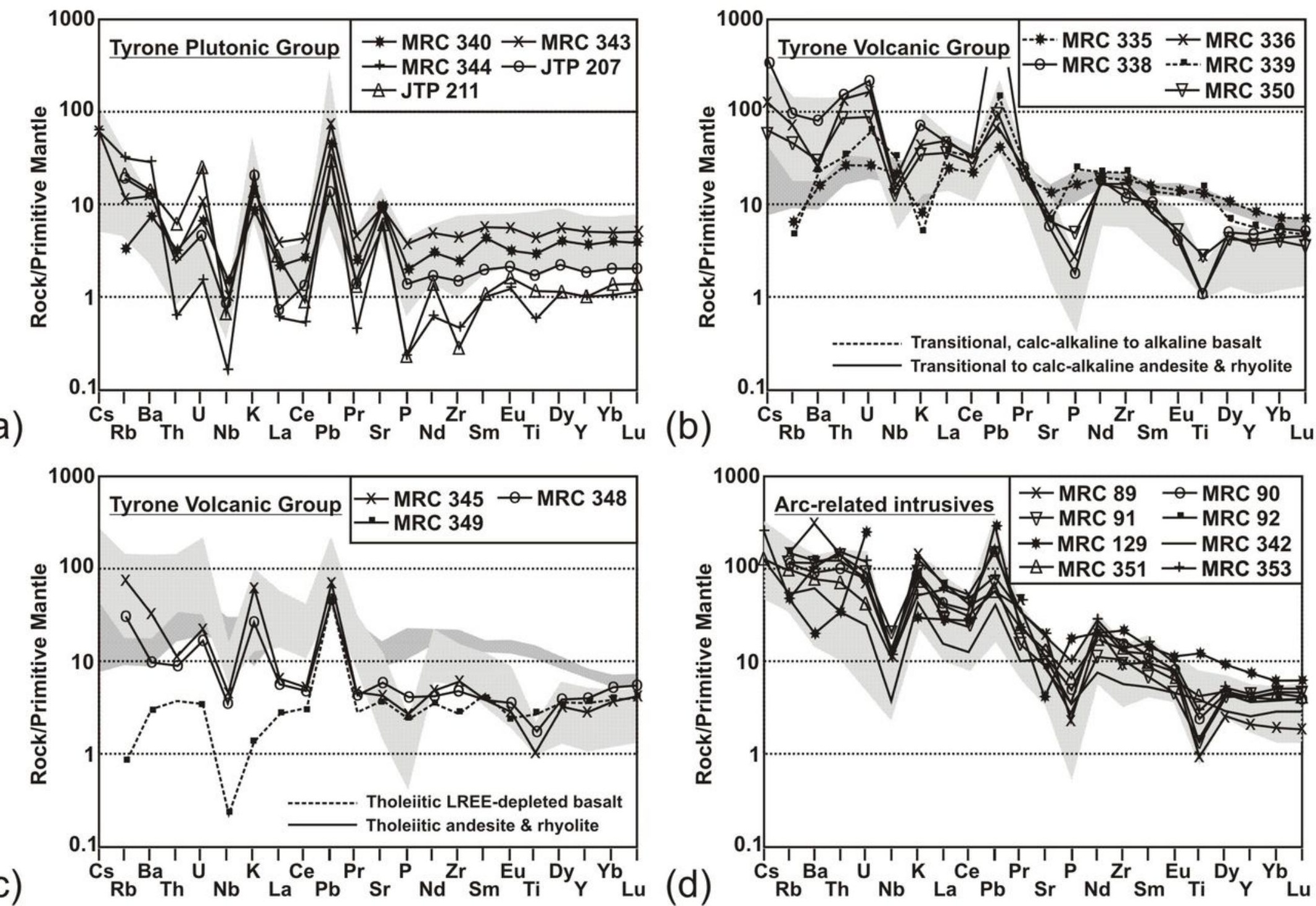


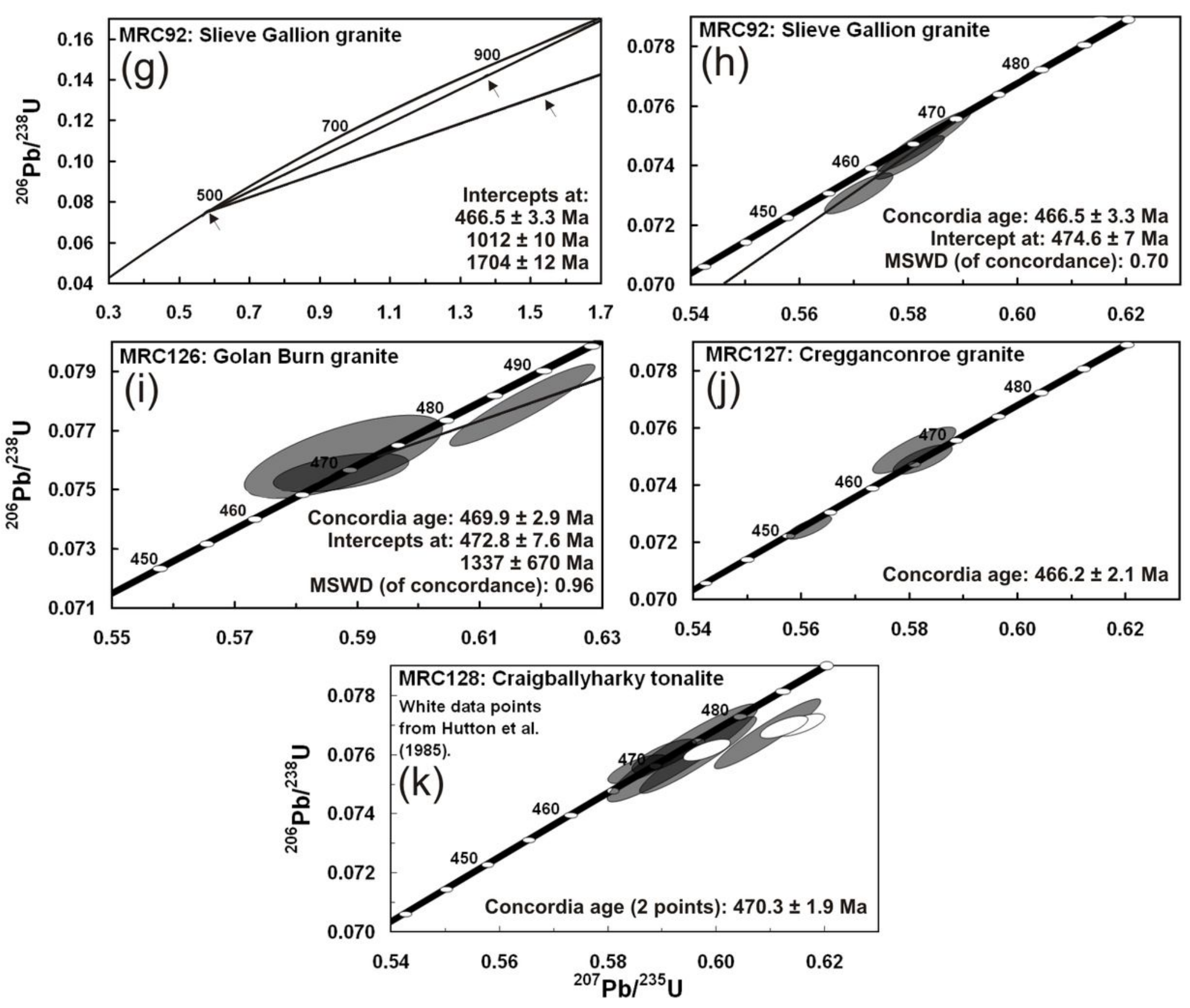


c. $480 \mathrm{Ma}$ :

Formation of Tyrone Plutonic Group / Ophiolite exhumation in w. Ireland

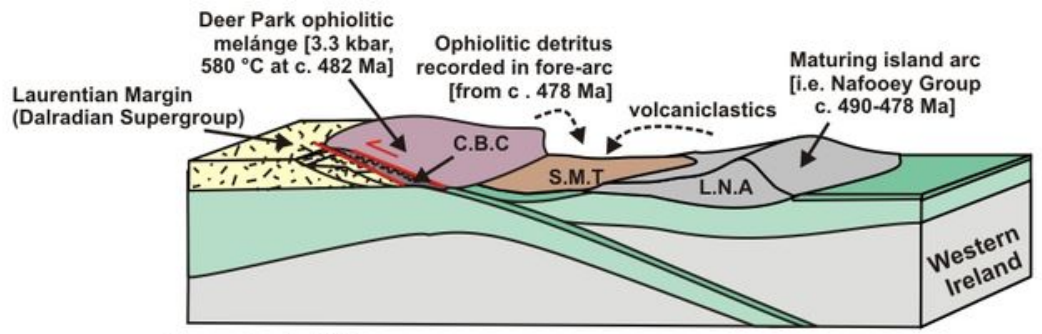

Tyrone Central Inlier

(outboard microcontinent?) Tyrone Plutonic

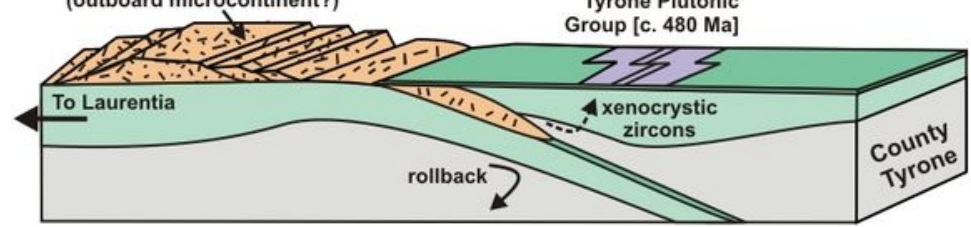

(a)

\section{c. 478-473 Ma:}

Evolution of Tyrone Volcanic Group / Collision in w. Ireland c. $478 \mathrm{Ma}$

Exhumation of ophiolite into South Mayo Trough

Laurentian Margin Ophiolitic [14 tuff bands Deposition Evolved syn-collisional

14 tuff bands volcanic arc

(Dalradian Supergroup) chrome-spinel in Sheeffry $\mathrm{Fm}$.]

[Tourmakeady Group

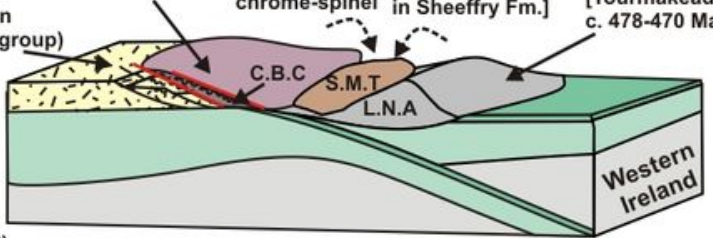

Tyrone Central Inlier (outboard microcontinent?)

\section{Laurentian detritus}

Intra-arc rifting

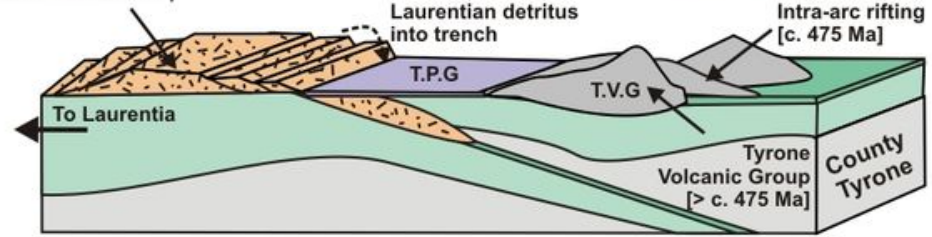

(b)

\section{c. 470-464 Ma:}

\section{Subduction polarity reversal \& magmatism}

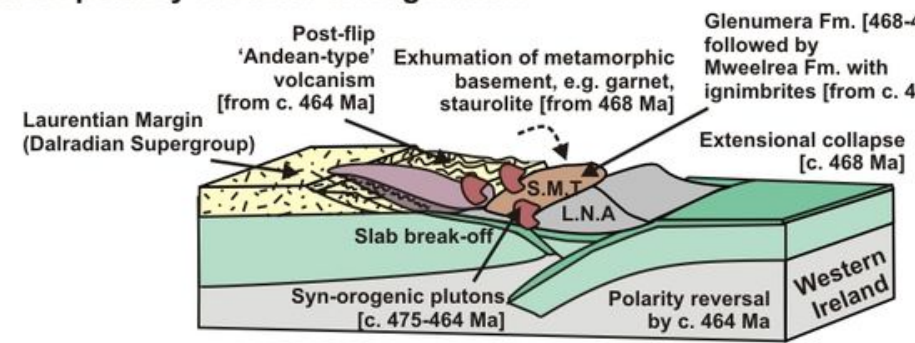

(c)

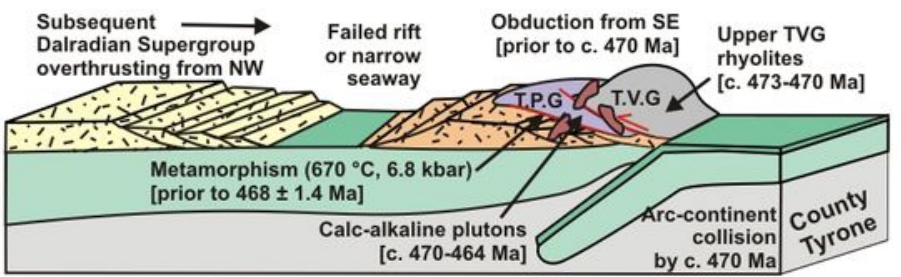


Table 1. U-Pb data for zircons and titanites from the intrusive suite, Tyrone Igneous Complex, Northern Ireland

\begin{tabular}{|c|c|c|c|c|c|c|c|c|c|c|c|c|}
\hline Zircon Fractions* & $\begin{array}{c}\mathrm{Wt} \\
(\mu \mathrm{g})^{\dagger}\end{array}$ & $\begin{array}{c}\mathrm{U} \\
(\mathrm{ppm})^{\dagger}\end{array}$ & $\begin{array}{c}\mathrm{Pb} \\
(\mathrm{ppm})^{\dagger}\end{array}$ & $\begin{array}{l}\mathrm{Cm} \mathrm{Pb} \\
(\mathrm{ppm})^{\dagger}\end{array}$ & ${ }^{206} \mathrm{~Pb} /{ }^{204} \mathrm{~Pb}^{\S}$ & ${ }^{208} \mathrm{~Pb} /{ }^{206} \mathrm{~Pb}^{\#}$ & ${ }^{206} \mathrm{~Pb} /{ }^{238} \mathrm{U}^{\#}$ & ${ }^{207} \mathrm{~Pb} /{ }^{235} \mathrm{U}^{\#}$ & ${ }^{207} \mathrm{~Pb} /{ }^{206} \mathrm{~Pb}^{\#}$ & $\begin{array}{c}{ }^{206} \mathrm{~Pb} /{ }^{238} \mathrm{U} \\
\text { age }(\mathrm{Ma})\end{array}$ & $\begin{array}{c}{ }^{207} \mathrm{~Pb} /{ }^{206} \mathrm{~Pb} \\
\text { age }(\mathrm{Ma}) \\
\end{array}$ & $\rho^{* *}$ \\
\hline \multicolumn{13}{|l|}{ JTP207: Scalp Layered Gabbro } \\
\hline 1. $173-20 \mathrm{NM}, 1: 1,45 \mu \mathrm{m}(1)$ & 0.4 & 239.0 & 30.25 & 1 & 144.4 & 0.0462 & $0.1704 \pm 2.1$ & $1.716 \pm 2.1$ & $0.07305 \pm 0.84$ & $1014.4 \pm 20.8$ & $1015.2 \pm 17.1$ & 0.92 \\
\hline 2. $173-30 \mathrm{NM}, 2: 1,100 \mu \mathrm{m}$ (1) & 0.8 & 273.2 & 22.48 & 1 & 208.7 & 0.3326 & $0.07747 \pm 1.3$ & $0.6063 \pm 1.6$ & $0.05676 \pm 0.93$ & $481.0 \pm 6.3$ & $482.3 \pm 20.4$ & 0.81 \\
\hline 3. $173-40 \mathrm{NM}, 2: 1,80 \mu \mathrm{m}(3)$ & 1.9 & 301.1 & 27.65 & 1 & 293.5 & 0.4120 & $0.07662 \pm 0.98$ & $0.6012 \pm 1.1$ & $0.05691 \pm 0.55$ & $475.9 \pm 4.7$ & $487.8 \pm 12.2$ & 0.86 \\
\hline 4. $173-50 \mathrm{NM}, 2: 1,100 \mu \mathrm{m}(1)$ & 0.9 & 239.4 & 28.03 & 6 & 139.1 & 0.4796 & $0.07727 \pm 0.23$ & $0.6116 \pm 1.7$ & $0.05740 \pm 0.66$ & $479.8 \pm 1.1$ & $507.1 \pm 14.6$ & 0.46 \\
\hline 5. $173-60 \mathrm{NM}, 2: 1,80 \mu \mathrm{m}(1)$ & 0.6 & 173.7 & 65.03 & 1 & 258.7 & 0.3002 & $0.3279 \pm 1.1$ & $5.743 \pm 1.1$ & $0.1270 \pm 0.28$ & $1828.3 \pm 20.1$ & $2056.9 \pm 4.9$ & 0.97 \\
\hline \multicolumn{13}{|l|}{ JTP209: Laght Hill Tonalite } \\
\hline 6. $209-20 \mathrm{NM}, 2: 1,80 \mu \mathrm{m}(5)$ & 23.2 & 235.5 & 21.11 & 7.3 & 352.9 & 0.1481 & $0.07478 \pm 0.28$ & $0.5844 \pm 1.5$ & $0.05668 \pm 1.5$ & $463.6 \pm 1.3$ & $479 \pm 33.5$ & 0.18 \\
\hline 7. 209-4 0NM, $2: 1,60-80 \mu \mathrm{m}(9)$ & 16.2 & 151.3 & 12.30 & 16 & 710.6 & 0.1568 & $0.07533 \pm 0.50$ & $0.5828 \pm 0.80$ & $0.05611 \pm 0.60$ & $465.9 \pm 2.3$ & $456.7 \pm 13.4$ & 0.67 \\
\hline 8. $209-60 \mathrm{NM}, 2: 1-4: 1,50-70 \mu \mathrm{m}(20)$ & 2.8 & 561.7 & 47.76 & 15 & 501.8 & 0.1890 & $0.07484 \pm 0.58$ & $0.5810 \pm 0.86$ & $0.05630 \pm 0.63$ & $462.6 \pm 2.6$ & $464.4 \pm 14.0$ & 0.67 \\
\hline 9. 209-7 0NM, 2:1-4:1, 80-100 $\mu \mathrm{m}$ (7) & 4.0 & 283.5 & 24.27 & 15 & 368.7 & 0.1681 & $0.07496 \pm 0.77$ & $0.5853 \pm 1.2$ & $0.05663 \pm 0.85$ & $462.5 \pm 3.5$ & $477.1 \pm 18.9$ & 0.67 \\
\hline \multicolumn{13}{|l|}{ MRC89: Pomeroy Granite } \\
\hline 10. 89-1 0NM, 5:1, $100 \mu \mathrm{m}(2)$ & 3.2 & 380.1 & 35.31 & 15 & 391.2 & 0.3256 & $0.07458 \pm 0.95$ & $0.5778 \pm 1.2$ & $0.05619 \pm 0.69$ & $459.4 \pm 4.3$ & $459.8 \pm 15.4$ & 0.81 \\
\hline 11. 89-2 0NM, $5: 1,80 \mu \mathrm{m}(2)$ & 1 & 854.6 & 83.49 & 15 & 278.8 & 0.3608 & $0.07501 \pm 1.3$ & $0.5904 \pm 1.6$ & $0.05709 \pm 0.86$ & $460.3 \pm 5.9$ & $494.9 \pm 19.1$ & 0.85 \\
\hline 12. 89-6 0NM, $2: 1,60 \mu \mathrm{m}(6)$ & 8.3 & 292.9 & 24.86 & 9 & 1256 & 0.2265 & $0.07517 \pm 0.41$ & $0.6092 \pm 0.46$ & $0.05878 \pm 0.20$ & $465.4 \pm 1.9$ & $558.9 \pm 4.4$ & 0.90 \\
\hline 13. 89-7 0NM, cl, 3:1, 40-60 $\mu \mathrm{m}(10)$ & 4.3 & 348.8 & 30.47 & 7 & 1006 & 0.2677 & $0.07469 \pm 0.35$ & $0.5811 \pm 0.56$ & $0.05642 \pm 0.42$ & $462.8 \pm 1.6$ & $469.1 \pm 9.3$ & 0.66 \\
\hline \multicolumn{13}{|l|}{ MRC90: Copney Quartz Porphyry } \\
\hline 14. $90-10 \mathrm{NM}, 3: 1,60-70 \mu \mathrm{m}(5)$ & 5.3 & 127.6 & 13.52 & 18 & 193.9 & 0.3909 & $0.07545 \pm 1.6$ & $0.5978 \pm 2.2$ & $0.05747 \pm 1.5$ & $461.7 \pm 7.2$ & $509.4 \pm 33.3$ & 0.73 \\
\hline 15. 90-2 0NM, 3:1, 60-70 $\mu \mathrm{m}(5)$ & 6.4 & 135.6 & 13.34 & 16 & 278.5 & 0.3588 & $0.07540 \pm 1.3$ & $0.5918 \pm 1.6$ & $0.05693 \pm 0.90$ & $462.7 \pm 5.9$ & $488.9 \pm 20.0$ & 0.82 \\
\hline 16. 90-4 0NM, 3:1, $80 \mu \mathrm{m}(3)$ & 5.1 & 135.1 & 12.73 & 5 & 666.8 & 0.3496 & $0.07485 \pm 0.45$ & $0.5815 \pm 0.68$ & $0.05635 \pm 0.50$ & $463.3 \pm 2.0$ & $466.1 \pm 11.1$ & 0.67 \\
\hline 17. $90-50 \mathrm{NM}, 3: 1,80 \mu \mathrm{m}(3)$ & 5.3 & 162.3 & 14.75 & 6 & 747.3 & 0.3493 & $0.07462 \pm 0.69$ & $0.5799 \pm 0.78$ & $0.05636 \pm 0.34$ & $460.8 \pm 3.1$ & $466.8 \pm 7.5$ & 0.90 \\
\hline \multicolumn{13}{|l|}{$\begin{array}{l}\text { MRC91: Craigbardahessiagh } \\
\text { Granodiorite }\end{array}$} \\
\hline 18. $91-30 \mathrm{NM}, \mathrm{mi}, 5: 1,70-100 \mu \mathrm{m}(5)$ & 9 & 185.5 & 16.69 & 7 & 1080 & 0.3351 & $0.07395 \pm 0.44$ & $0.5760 \pm 1.0$ & $0.05650 \pm 0.89$ & $458.0 \pm 2.0$ & $471.9 \pm 19.8$ & 0.52 \\
\hline 19. 91-4 0NM, 5:1, 70-100 $\mu \mathrm{m}(5)$ & 11 & 150.1 & 15.26 & 35 & 240.1 & 0.2862 & $0.07503 \pm 0.69$ & $0.5831 \pm 2.0$ & $0.05636 \pm 1.8$ & $463.3 \pm 3.1$ & $466.6 \pm 40.4$ & 0.35 \\
\hline 20. $91-50 \mathrm{NM}, 1: 1-2: 1,60-80 \mu \mathrm{m}(6)$ & 5.4 & 219.1 & 31.92 & 13 & 817.4 & 0.1260 & $0.1390 \pm 0.55$ & $1.405 \pm 0.60$ & $0.07334 \pm 0.23$ & $834.7 \pm 4.3$ & $1023.2 \pm 4.7$ & 0.93 \\
\hline 21.91-6 Titanite & 138 & 256.0 & 35.42 & 1420 & 130.5 & 0.4523 & $0.07471 \pm 0.37$ & $0.5769 \pm 4.9$ & $0.05600 \pm 4.9$ & $462.8 \pm 1.7$ & $452 \pm 112$ & 0.02 \\
\hline 22.91-7 Titanite & 47.1 & 190.4 & 28.35 & 490 & 98.50 & 0.5466 & $0.06999 \pm 0.49$ & $0.5417 \pm 6.8$ & $0.05614 \pm 6.8$ & $434.0 \pm 2.1$ & $458 \pm 158$ & 0.02 \\
\hline 23. 91-8 0NM, 3:1, $80 \mu \mathrm{m}(6)$ & 3.3 & 216.2 & 21.17 & 6 & 578.9 & 0.2883 & $0.08112 \pm 0.59$ & $0.6759 \pm 0.85$ & $0.06042 \pm 0.59$ & $500.0 \pm 2.9$ & $618.8 \pm 12.8$ & 0.72 \\
\hline \multicolumn{13}{|l|}{ MRC92: Slieve Gallion Granite } \\
\hline 24. $92-10 \mathrm{NM}, 2: 1,100 \mu \mathrm{m}(1)$ & 7 & 347.0 & 47.92 & 12 & 1869 & 0.0582 & $0.1417 \pm 0.33$ & $1.374 \pm 0.36$ & $0.07031 \pm 0.15$ & $851.6 \pm 2.6$ & $937.4 \pm 3.1$ & 0.92 \\
\hline 25. 92-2 0NM, $2: 1,80 \mu \mathrm{m}(2)$ & 6.3 & 228.7 & 20.03 & 13 & 510.6 & 0.2745 & $0.07434 \pm 0.81$ & $0.5804 \pm 0.91$ & $0.05662 \pm 0.40$ & $458.6 \pm 3.6$ & $476.8 \pm 8.9$ & 0.90 \\
\hline 26. $92-30 \mathrm{NM}, 4: 1,80 \mu \mathrm{m}(3)$ & 4.7 & 213.3 & 18.50 & 12 & 409.6 & 0.2596 & $0.07490 \pm 1.1$ & $0.5830 \pm 1.2$ & $0.05645 \pm 0.42$ & $460.6 \pm 4.9$ & $470.1 \pm 9.3$ & 0.94 \\
\hline 27. 92-4 0NM, 2:1, 60-80 $\mu \mathrm{m}(5)$ & 4.8 & 321.9 & 28.35 & 15 & 473.0 & 0.2861 & $0.07313 \pm 0.77$ & $0.5710 \pm 0.91$ & $0.05663 \pm 0.49$ & $451.6 \pm 3.4$ & $477.1 \pm 10.9$ & 0.84 \\
\hline 28. 92-6 0NM, 1:1-2:1, 70-100 $\mu \mathrm{m}(8)$ & 11.6 & 253.7 & 36.69 & 14 & 1749 & 0.1639 & $0.1326 \pm 0.30$ & $1.538 \pm 0.36$ & $0.08410 \pm 0.20$ & $800.4 \pm 2.3$ & $1294.9 \pm 3.9$ & 0.84 \\
\hline 29. 92-7 0NM, 1:1-2:1, 60-80 $\mu \mathrm{m}(12)$ & 14.3 & 227.7 & 22.11 & 19 & 937.2 & 0.2107 & $0.08719 \pm 0.49$ & $0.8022 \pm 0.54$ & $0.06673 \pm 0.22$ & $536.4 \pm 2.5$ & $829.5 \pm 4.6$ & 0.92 \\
\hline \multicolumn{13}{|l|}{ MRC126: Golan Burn Tonalite } \\
\hline 30. 126-1 0NM, 2:1-3:1, 80-100 $\mu \mathrm{m}(5)$ & 5.2 & 103.2 & 10.73 & 14 & 196.2 & 0.3392 & $0.07607 \pm 1.5$ & $0.5977 \pm 2.3$ & $0.05603 \pm 1.7$ & $465.8 \pm 6.8$ & $453.5 \pm 38.2$ & 0.68 \\
\hline 31. 126-4 0NM, i, 5:1, $100 \mu \mathrm{m}(6)$ & 12.4 & 91.5 & 8.47 & 17 & 351.4 & 0.3044 & $0.07781 \pm 1.5$ & $0.6169 \pm 1.6$ & $0.05750 \pm 0.56$ & $476.1 \pm 7.0$ & $510.9 \pm 13.4$ & 0.93 \\
\hline
\end{tabular}




\begin{tabular}{|c|c|c|c|c|c|c|c|c|c|c|c|c|}
\hline 32. 126-5 0NM, i, 5:1, $100 \mu \mathrm{m}(6)$ & 13.8 & 87.8 & 8.4 & 15 & 537.9 & 0.3207 & $0.07554 \pm 0.70$ & $0.5874 \pm 1.5$ & $0.05640 \pm 1.3$ & $466.3 \pm 3.2$ & $468 \pm 29.1$ & 0.53 \\
\hline \multicolumn{13}{|l|}{$\begin{array}{l}\text { MRC127: Cregganconroe Quartz- } \\
\text { monzodiorite }\end{array}$} \\
\hline 33. $127-2$ 0NM, $1: 1-2: 1,40-60 \mu \mathrm{m}(12)$ & 7.4 & 207.3 & 18.71 & 14 & 537.9 & 0.2788 & $0.07497 \pm 0.56$ & $0.5827 \pm 0.77$ & $0.05637 \pm 0.52$ & $463.5 \pm 2.5$ & $467.1 \pm 11.6$ & 0.73 \\
\hline $\begin{array}{l}\text { 34. } 127-30 \mathrm{NM}, \mathrm{i}, \mathrm{f}, 6: 1,150-200 \mu \mathrm{m} \\
\text { (5) }\end{array}$ & 6.4 & 310.6 & 26.52 & 12 & 742.1 & 0.2706 & $0.07259 \pm 0.46$ & $0.5617 \pm 0.60$ & $0.05612 \pm 0.38$ & $449.7 \pm 2.0$ & $457.0 \pm 8.5$ & 0.77 \\
\hline $\begin{array}{l}35.127-40 \mathrm{NM}, \mathrm{i}, \mathrm{f}, 6: 1,150-200 \mu \mathrm{m} \\
\text { (6) }\end{array}$ & 8 & 242.1 & 22 & 21 & 450.1 & 0.2986 & $0.07529 \pm 0.89$ & $0.5811 \pm 1.1$ & $0.05598 \pm 0.60$ & $463.9 \pm 4.0$ & $451.5 \pm 13.4$ & 0.83 \\
\hline \multicolumn{13}{|l|}{ MRC128: Craigballyharky Tonalite } \\
\hline 36. 128-1 0NM, 1:1-2:1, 70-90 بm (4) & 15.2 & 92.5 & 8.65 & 11 & 614.4 & 0.3332 & $0.07598 \pm 0.61$ & $0.5905 \pm 0.83$ & $0.05637 \pm 0.54$ & $469.3 \pm 2.8$ & $466.8 \pm 12.0$ & 0.76 \\
\hline 37. $128-20 \mathrm{NM}, 1: 1-2: 1,40-60 \mu \mathrm{m}(12)$ & 12 & 77.6 & 7.17 & 20 & 240.5 & 0.2778 & $0.07608 \pm 1.8$ & $0.5939 \pm 1.9$ & $0.05661 \pm 0.72$ & $464.5 \pm 8.2$ & $476.6 \pm 16.0$ & 0.93 \\
\hline 38. 128-3 0NM, i, f, $4: 1,200 \mu \mathrm{m}(3)$ & 14.9 & 81.8 & 7.43 & 17 & 358.8 & 0.3078 & $0.07601 \pm 1.4$ & $0.5967 \pm 1.5$ & $0.05693 \pm 0.49$ & $465.9 \pm 6.4$ & $488.9 \pm 10.9$ & 0.94 \\
\hline 39. 128-4 0NM, i, 4:1 $200 \mu \mathrm{m}(3)$ & 16.8 & 97.4 & 8.61 & 12 & 643.5 & 0.2580 & $0.07553 \pm 0.54$ & $0.5856 \pm 0.76$ & $0.05623 \pm 0.52$ & $466.9 \pm 2.5$ & $461.3 \pm 11.6$ & 0.73 \\
\hline $\begin{array}{l}\text { 40. } 128-50 \mathrm{NM}, \mathrm{i}, \mathrm{f}, 5: 1,100-150 \mu \mathrm{m} \\
\text { (6) }\end{array}$ & 15.1 & 95.2 & 8.93 & 19 & 382.7 & 0.3222 & $0.07674 \pm 1.3$ & $0.6096 \pm 1.3$ & $0.05761 \pm 0.43$ & $470.7 \pm 6.0$ & $515.0 \pm 9.5$ & 0.94 \\
\hline
\end{tabular}

Notes: * Zircon grain characteristics specified as: $\mathrm{x}^{\circ} \mathrm{N}=$ non-magnetic, at specified tilt angle on a Frantz LB-1 Separator at 1.7 amps; mi $=$ abundant melt inclusions, $i=$ opaque inclusions: $X: 1=$ aspect ratios of grains; lengths of grains in $\mu \mathrm{m}$, number of grains analysed in ( ). $\dagger$ Maximum errors are $\pm 20 \%$. Weights were measured on a Cahn C32 microbalance. § Measured ratio corrected for fractionation and spike Pb. \# Corrected for fractionation, spike, laboratory blank $\mathrm{Pb}$ and $\mathrm{U}$, and initial common Pb estimated from Stacey \& Kramers, 1975. Laboratory blank $\mathrm{Pb}$ composition is ${ }^{206} \mathrm{~Pb} /{ }^{204} \mathrm{~Pb}:{ }^{207} \mathrm{~Pb} /{ }^{204} \mathrm{~Pb}:{ }^{208} \mathrm{~Pb} /{ }^{204} \mathrm{~Pb}=18.19: 15.58: 38.50$. Quoted errors are $2 \sigma(\%$ for atomic ratios, absolute for ages $) .{ }^{* *}{ }^{207} \mathrm{~Pb} /{ }^{235} \mathrm{U}-{ }^{206} \mathrm{~Pb} /{ }^{238} \mathrm{U}$ error correlation coefficient calculated following Ludwig (2003). 
Table 2. Calculated U-Pb zircon ages and additional information for analysed samples. Previously published U-Pb geochronology for Tyrone Igneous Complex also included.

\begin{tabular}{|c|c|c|c|}
\hline Lithological Unit & Age $(\mathrm{Ma})$ & Calculated On & Additional Information \\
\hline $\begin{array}{l}\text { Scalp Layered Gabbro } \\
\text { (JTP207) }\end{array}$ & $479.6 \pm 1.1$ & $\begin{array}{l}\text { Three concordant } \\
\text { zircon analyses }\end{array}$ & $\begin{array}{l}\text { Two zircon fractions gave inherited ages of } c .1015 \mathrm{Ma} \text { (concordant) and } 2100 \mathrm{Ma} \text { (upper intercept anchored } \\
\text { at } 479.6 \mathrm{Ma} \text { ). }\end{array}$ \\
\hline $\begin{array}{l}\text { Laght Hill Tonalite } \\
\text { (JTP209) }\end{array}$ & $465.6 \pm 1.1$ & $\begin{array}{l}\text { Four concordant } \\
\text { analyses }\end{array}$ & This tonalite provided a low yield of inheritance free zircon. \\
\hline $\begin{array}{l}\text { Golan Burn Tonalite } \\
\text { (MRC126) }\end{array}$ & $469.9 \pm 2.9$ & $\begin{array}{l}\text { Two concordant } \\
\text { zircon analyses }\end{array}$ & $\begin{array}{l}\text { Zircons separated from this sample were generally free from inheritance, but contained melt and mineral } \\
\text { inclusions. Three zircon analyses yielded concordant to near-concordant analyses. Third analysis shows a } \\
\text { small degree of inheritance. }\end{array}$ \\
\hline $\begin{array}{l}\text { Cregganconroe Quartz- } \\
\text { monzodiorite (MRC127) }\end{array}$ & $466.2 \pm 2.1$ & $\begin{array}{l}\text { Two concordant } \\
\text { zircon analyses }\end{array}$ & $\begin{array}{l}\text { A small proportion of zircons from this sample displayed visible inherited components and these were } \\
\text { avoided. A third point was discordant along a shallow Pb-loss trajectory. }\end{array}$ \\
\hline $\begin{array}{l}\text { Craigballyharky Tonalite } \\
\text { (MRC128) }\end{array}$ & $470.3 \pm 1.9$ & $\begin{array}{l}\text { Two concordant } \\
\text { zircon analyses }\end{array}$ & $\begin{array}{l}\text { These new data are consistent with that of Hutton et al. (1985) for the same sample site. Plotting these new U- } \\
\mathrm{Pb} \text { data with those of Hutton et al. gives a lower intercept age of } 471.2^{+2.0} \%_{-2.3} \mathrm{Ma} \text { and an upper intercept of } \\
2101^{+400} /_{-350} \mathrm{Ma} \text { indicating an inherited component at c. } 2100 \mathrm{Ma} \text {. }\end{array}$ \\
\hline $\begin{array}{l}\text { Pomeroy Granite } \\
\text { (MRC89) }\end{array}$ & $464.3 \pm 1.5$ & $\begin{array}{l}\text { Two concordant } \\
\text { zircon analyses. }\end{array}$ & The zircons analysed are predominantly acicular neocrystalline with rare visible inherited cores. \\
\hline $\begin{array}{l}\text { Copney Quartz Porphyry } \\
\text { (MRC90) }\end{array}$ & $465.0 \pm 1.7$ & $\begin{array}{l}\text { Two concordant } \\
\text { zircon analyses. }\end{array}$ & $\begin{array}{l}\text { Zircons recovered are very similar to those described for the Pomeroy granite. A discordia yields a lower } \\
\text { intercept age of } 464.6 \pm 2.3 \mathrm{Ma} \text { and an upper intercept of c. } 2150 \mathrm{Ma} \text {. }\end{array}$ \\
\hline $\begin{array}{l}\text { Craigbardahessiagh } \\
\text { Granodiorite } \\
\text { (MRC91) }\end{array}$ & $464.9 \pm 1.5$ & $\begin{array}{l}\text { One analysis each of } \\
\text { titanite and zircon } \\
\text { are concordant }\end{array}$ & $\begin{array}{l}\text { Zircons show both inheritance and Pb-loss, while some titanites analysed exhibit Pb loss. Most data plot near } \\
465 \mathrm{Ma} \text { on the concordia diagram, but two zircon analyses show a significant Mesoproterozoic (c. } 1185-1512 \\
\text { Ma) inherited component. }\end{array}$ \\
\hline $\begin{array}{l}\text { Slieve Gallion Granite } \\
\text { (MRC92) }\end{array}$ & $466.5 \pm 3.3$ & $\begin{array}{l}\text { One concordant } \\
\text { analysis }\end{array}$ & $\begin{array}{l}\text { This granite contains both core-free zircons and those with clearly visible cores. Two analyses of inherited } \\
\text { zircons have Mesoproterozoic ages from } c \text {. } 1000 \mathrm{Ma} \text { to } 1700 \mathrm{Ma} \text {. Three analyses of core-free grains are } \\
\text { concordant to slightly discordant, and yield an upper intercept age of } 474.6^{+7.1} /-6.9 \text { Ma. The most concordant } \\
\text { analysis has an age of } 466.5 \pm 3.3 \mathrm{Ma} \text { and this is considered to be the best estimate of the intrusion age. }\end{array}$ \\
\hline \multicolumn{4}{|l|}{ Previous Geochronology: } \\
\hline $\begin{array}{l}\text { Leaghan tonalite of } \\
\text { Draut et al. }(2009)\end{array}$ & $475 \pm 10$ & Ten zircon analyses & U-Pb zircon SHRIMP. Archaean cores identified in three zircon grains using SHRIMP and LA-MC-ICP-MS. \\
\hline $\begin{array}{l}\text { Craigballyharky Gabbro of } \\
\text { Draut et al. (2009) }\end{array}$ & $493 \pm 2$ & $\begin{array}{l}\text { Three concordant } \\
\text { zircon analyses }\end{array}$ & $\begin{array}{l}\text { U-Pb zircon SHRIMP. The weighted mean }{ }^{238} \mathrm{U} /{ }^{206} \mathrm{~Pb} \text { age of the oldest three concordant ages from the gabbro } \\
\text { was } 493 \pm 2 \mathrm{Ma} \text {. Three younger zircons with ages around c. } 470 \mathrm{Ma} \text { were attributed to contamination. }\end{array}$ \\
\hline $\begin{array}{l}\text { Formil Rhyolite of Cooper } \\
\text { et al. }(2008)\end{array}$ & $473.0 \pm 0.8$ & $\begin{array}{l}\text { Three concordant } \\
\text { zircon analyses. }\end{array}$ & U-Pb zircon TIMS. No inheritance noted by authors. \\
\hline $\begin{array}{l}\text { Craigballyharky Tonalite } \\
\text { of Hutton et al. (1985) }\end{array}$ & $471+2-4 \mathrm{Ma}$ & $\begin{array}{l}\text { Three zircon size } \\
\text { fractions. }\end{array}$ & $\begin{array}{l}\text { U-Pb zircon TIMS. Analyses are moderately discordant and define a discordia line with an upper intercept of } \\
2030+630{ }_{-500} \mathrm{Ma} \text { and lower intercept of } 471^{+2} /{ }_{-4} \mathrm{Ma} \text {. }\end{array}$ \\
\hline
\end{tabular}

